\title{
Investigations on the Degradation of Triazine Herbicides in Water by Photo-Fenton Process
}

\author{
Sondos Dbira1 ${ }^{1}$, Ahmed Bedoui ${ }^{1}$, Nasr Bensalah ${ }^{2 *}$ \\ ${ }^{1}$ Department of Chemistry, Faculty of Sciences of Gabes, University of Gabes, Gabes, Tunisia \\ ${ }^{2}$ Department of Chemistry and Earth Sciences, College of Arts and Sciences, Qatar University, Doha, Qatar \\ Email: nasr.bensalah@qu.edu.qa, nasr.bensalah@issatgb.rnu.tn
}

Received 16 April 2014; revised 31 May 2014; accepted 15 June 2014

Copyright (C) 2014 by authors and Scientific Research Publishing Inc.

This work is licensed under the Creative Commons Attribution International License (CC BY). http://creativecommons.org/licenses/by/4.0/

(c) (i) Open Access

\begin{abstract}
In this work, the degradation of 2-chloro-4,6-diamino-1,3,5-triazine in aqueous solutions by photo-Fenton process has been investigated. The preliminary results have shown that the degradation of 2-chloro-4,6-diamino-1,3,5-triazine by photo-Fenton process is more rapid and more effective than Fenton and $\mathrm{UV} / \mathrm{H}_{2} \mathrm{O}_{2}$ processes. The effects of certain experimental parameters on kinetics and efficiency of the degradation of 2-chloro-4,6,-diamino-1,3,5-triazine by photo-Fenton process, have been evaluated. Under optimal conditions, photo-Fenton process achieved more than $90 \%$ of chloride release and about $30 \%$ of nitrate formation. The results of total organic carbon (TOC) and total Kjeldahl nitrogen (TKN) analyses have shown that no carbon dioxide and ammonia are formed during photo-Fenton treatment of aqueous solutions containing $40 \mathrm{mg} / \mathrm{L}$ triazine. These results indicate that only substituent groups of triazine ring are released; however, nitrogen atoms of triazine ring remain unaffected. A simple mechanism of degradation of 2-chloro-4,6-diamino-1,3,5-triazine has been proposed. The degradation starts by a rapid release of chlorine atoms as chloride ions to form 2-hydroxy-4,6-diamino-1,3,5-triazine. The amino groups of 2-hydroxy-4,6-diamino-1,3,5-triazine undergo are oxidized into nitro groups by hydroxyl radicals to form 2-hydroxy-4,6-dinitro-1,3,5-triazine which undergoes a slow release of nitro groups and their substitution with hydroxyl groups to form cyanuric acid and nitrate ions. The degradation of cyanuric acid by photo-Fenton process has also been investigated. The results of TOC and TKN analyzes show that no carbon dioxide is formed during the treatment.
\end{abstract}

\section{Keywords}

Photo-Fenton Process, Hydroxyl Radicals, s-Triazine Herbicides, Degradation, Cyanuric Acid

*Corresponding author.

How to cite this paper: Dbira, S., Bedoui, A. and Bensalah, N. (2014) Investigations on the Degradation of Triazine Herbicides in Water by Photo-Fenton Process. American Journal of Analytical Chemistry, 5, 500-517. 


\section{Introduction}

Pesticides are chemical substances widely used in agriculture to fight against different types of organisms that are harmful (bacteria, insects and weeds) for crops [1]-[3]. Pesticides are xenobiotic, toxic and non-biodegradable and can cause serious problems to human health and environment [4]-[6]. Herbicides constitute the principal class of pesticides especially used in agriculture to protect the crops plant against weeds. The class of s-triazine is the largest proportion of herbicides used in agriculture and horticulture. S-triazines are hetero-aromatic rings substituted with amino $\left(-\mathrm{NH}_{2}\right)$ and chloro $(-\mathrm{Cl})$ groups. The hetero-aromatic rings contain alternately three nitrogen atoms and three carbon atoms. If nitrogen atoms are in positions 1,3,5 of hetero-aromatic ring, it is known as s-triazine ring. The chemical structures of s-triazines are given in Figure 1. Atrazine, simazine, cyanazine, prometon, propazine are the common triazines utilized in agriculture and horticulture. Atrazine is very commonly used to fight against weeds in crops and public gardens. Triazine herbicides are persistent, toxic and bio-resistant in the environment and have been detected in drinking water [3]-[9]. It is essential to find an effective and economic method of treatment capable to completely eliminate these pollutants from natural water. However, microbial degradation of triazines herbicides was limited to a partial degradation of these compounds [10]. Conventional physico-chemical methods used for the removal of herbicides from water such as flocculation, filtration and activated carbon adsorption are not suitable to reduce the concentration of s-triazines to concentrations less than maximum contaminant levels regulated by the environmental protection agencies.

Advanced oxidation processes (AOPs) have been considered as promising alternative to conventional methods of water treatment especially when the later fail to completely destroy or remove enough persistent and bio-resistant organic pollutants. Advanced oxidation processes are based on the production in situ of free oxidizing radical species mainly hydroxyl radicals $\left(\mathrm{HO}^{*}\right)$. These radicals can be generated by chemical (Fenton $\left(\mathrm{H}_{2} \mathrm{O}_{2} / \mathrm{Fe}^{2+}\right)$ [11] [12], ozonation at alkaline medium [13], peroxonation $\left(\mathrm{O}_{3} / \mathrm{H}_{2} \mathrm{O}_{2}\right)$ [14], photochemical UV/TiO [15] [16] $\mathrm{UV} / \mathrm{H}_{2} \mathrm{O}_{2}$ [17] [18], $\mathrm{UV} / \mathrm{O}_{3}$ [19], photo-Fenton $\mathrm{UV} / \mathrm{H}_{2} \mathrm{O}_{2} / \mathrm{Fe}^{2+}$ [20] [21], and electrochemical (anodic oxidation, electro-Fenton) [22] [23]. Hydroxyl radicals are powerful oxidants $\left(\mathrm{E}^{\circ}=2.80 \mathrm{~V} / \mathrm{NHE}\right)$, which react immediately and non-selectively with organic pollutants in water which leads in most cases to a complete mineralization these compounds or to transform them into readily biodegradable compounds. Advanced oxidation processes (AOPs) have been effective for the mineralization of several types of organic pollutants such as phenols, polyphenols, aromatic dyes, pharmaceuticals, etc. [24]-[29]. In particular, photo-Fenton $\mathrm{UV} / \mathrm{H}_{2} \mathrm{O}_{2}$ is often successfully used in removing pollutants in various wastewater treatments. This method (Equations (1) and (2)) represents the decomposition of hydrogen peroxide into hydroxyl radical, which occurs through two routes: (1) catalytic decomposition by ferrous iron and (2) photodecomposition by UV irradiation.

$$
\begin{gathered}
\mathrm{Fe}^{2+}+\mathrm{H}_{2} \mathrm{O}_{2} \rightarrow \mathrm{Fe}^{3+}+\mathrm{HO}^{?}+\mathrm{HO}^{-} \\
\mathrm{H}_{2} \mathrm{O}_{2}+h \vartheta \rightarrow 2 \mathrm{HO}^{\circ}
\end{gathered}
$$

Several researchers have studied the degradation of atrazine by different advanced oxidation processes [30][32]. The results showed that atrazine was degraded rapidly with the formation of several intermediates such as 2-chloro-4,6-diamino-1,3,5-triazine and cyanuric acid (see Figure 1) [31]. However, this herbicide did not fully mineralize to $\mathrm{CO}_{2}, \mathrm{H}_{2} \mathrm{O}, \mathrm{Cl}^{-}$and $\mathrm{NO}_{3}^{-}$(or $\mathrm{NH}_{3}$ ). Rather, degradation of atrazine was stopped at 2-chloro-4,6diamino-1,3,5-triazine and cyanuric acid. Watanabe et al. [33] showed that no degradation was obtained by treating cyanuric acid with Fenton's reagent and photolysis $\mathrm{UV} / \mathrm{TiO}_{2}$.

The aim of the present work was to 1 ) investigate the treatment process of synthetically prepared wastewaters contaminated with two intermediates of atrazine degradation: 2-chloro-4 ,6-diamino-1,3,5-triazine and cyanuric acid by photo-Fenton and 2) to evaluate the effects of certain experimental parameters such as $\mathrm{H}_{2} \mathrm{O}_{2}$ concentra-

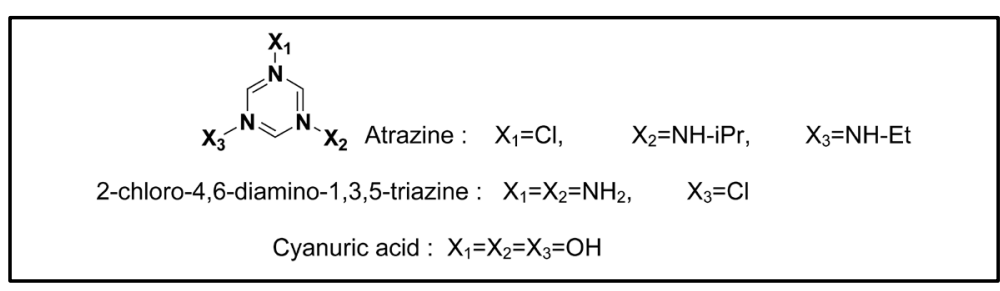

Figure 1. Structures of atrazine and its degradation intermediates. 
tion, ferrous iron dose, initial $\mathrm{pH}$, triazine concentration and UV light on the kinetics and efficiency of triazine degradation by photo-Fenton process to find out the optimal degradation and mineralization conditions.

\section{Experimental}

\subsection{Chemicals}

2-chloro-4,6-diamino-1,3,5-triazine and cyanuric acid were purchased from Fluka. Hydrogen peroxide was a $30 \%(w / w)$ solution (Fluka). Other chemicals such as hyptohydrated ferrous sulfate, sulfuric acid, sodium hydroxide and sodium sulfite were of analytical grade and were purchased from Sigma-Aldrich or Merck. All solutions were prepared with deionized water having $18 \mathrm{~m} \Omega \cdot \mathrm{cm}^{-1}$ resistivity from a Mill-Q ${ }^{\mathrm{TM}}$ system.

\subsection{Analytical Method}

The formation of inorganic ions (nitrate, nitrite, chloride) was determined using a Dionex ICS 2000 ion chromatograph equipped with an AS autosampler, Ion Pac AG 19 (4 mm $\times 50 \mathrm{~mm}$ ) guard column, Ion Pac AS 19 (4 $\mathrm{mm} \times 250 \mathrm{~mm}$ ) analytical column separation, ASRS $300 \mathrm{~mm}-4 \mathrm{~mm}$ suppressor, DS6 conductimetric cell and EGC eluent generator. The mobile phase is an aqueous solution of potassium hydroxide $\mathrm{KOH}$ prepared by dilution of $1 \mathrm{M}$ aqueous solution of $\mathrm{KOH}$.

The total organic carbon (TOC) and total nitrogen (TN) were monitored with a Skalar Formacs ${ }^{\mathrm{HT}}$ TOC/TN analyzer. Absorbance measurements were determined by a Perkin Elmer Lambda 5 UV-Visible spectrophotometer using a quartz cells $(1 \mathrm{~cm})$. To eliminate the influence of $\mathrm{pH}$ on the variation of UV-Visible spectra, all solutions were used at $\mathrm{pH}$ natural.

\subsection{Photo-Fenton Process}

The photochemical experiments were carried out in the reactor equipped with a UV lamp (TNN 15/32, 15 W) mercury vapor a magnetic stirrer and a thermometer. The photo-reactor (pyrex) of $0.5 \mathrm{~L}(500 \mathrm{~mL}$ ) capacity was placed in the first part. The lamp was located in an axial position submerged in a vertical immersion tube contained in a vertical cooling tube and immersed in the solution. Water was circulated between the lamp and glass vessel. The experience was mounted on a magnetic stirrer. In this work, only mercury vapor lamps that emit irradiation primarily to about $254 \mu \mathrm{m}$ coincide with the absorption of our reagent is $\mathrm{H}_{2} \mathrm{O}_{2}$. All experiments used $500 \mathrm{~mL}$ of the solution. The solution $\mathrm{pH}$ was adjusted to the desired values by addition of sodium hydroxide or sulfuric acid. After the light of the lamp, a precise amount of hydrogen peroxide $30 \%$ was mixed with $500 \mathrm{~mL}$ of the solution $10 \mathrm{~mL}$ samples were periodically collected. The reaction was quenched with $\mathrm{Na}_{2} \mathrm{SO}_{3}$, then analyzed immediately to determined $\mathrm{pH}$. The samples were filtered through membranes and injected in the ion chromatograph, TOC and TKN.

\section{Results and Discussion}

\subsection{Degradation of 2-Chloro-4,6-diamino-1,3,5-triazine by Fenton, Photo-Fenton and $\mathrm{UV} / \mathrm{H}_{2} \mathrm{O}_{2}$ Processes}

The degradation of 2-chloro-4,6-diamino-1,3,5-triazine was followed with UV-visible spectrometry, ion chromatography analysis and TOC and TKN measurements. UV-Visible spectra of aqueous solutions containing various concentration of 2-chloro-4,6-diamino-1,3,5-triazine are shown in Figure 2(a). The UV-Visible spectra of 2-chloro-4,6-diamino-1,3,5-triazine presents two absorption bands at $208 \mathrm{~nm}$ and $255 \mathrm{~nm}$. The band at $208 \mathrm{~nm}$ can be attributed to $\pi \rightarrow \pi^{*}$ transition of the triazine ring. While, the band at $255 \mathrm{~nm}$ was most likely due to $\mathrm{n} \rightarrow \pi^{*}$ transition in amino groups $\left(-\mathrm{NH}_{2}\right)$ substituent the triazine ring. The band at $208 \mathrm{~nm}$ cannot be used to measure the concentration of 2-chloro-4,6-diamino-1,3,5-triazine because the chemical species initially present in the reaction medium such as $\mathrm{H}_{2} \mathrm{O}_{2}, \mathrm{Fe}^{2+}, \mathrm{SO}_{4}^{2-}$ or formed during the treatment by photo-Fenton process such as carboxylic acids, $\mathrm{NO}_{3}^{-}$and $\mathrm{NO}_{2}^{-}$absorb UV light in the same range from 200 to $220 \mathrm{~nm}$. The band at $255 \mathrm{~nm}$ is characteristic of 2-chloloro-4,6-diamino-1,3,5-triazine in water. Figure 2(b) shows that the changes of absorbance at the wavelength $\lambda=255 \mathrm{~nm}$ with the concentration of 2-chloro-4,6-diamino-1,3,5-triazine in the field of concentration of $4-40 \mathrm{ppm}$. The change of the absorbance at $255 \mathrm{~nm}$ with the triazine concentration is linear curve passing by the origin which indicates that Beer's law is verified. This indicates that non-negligible 


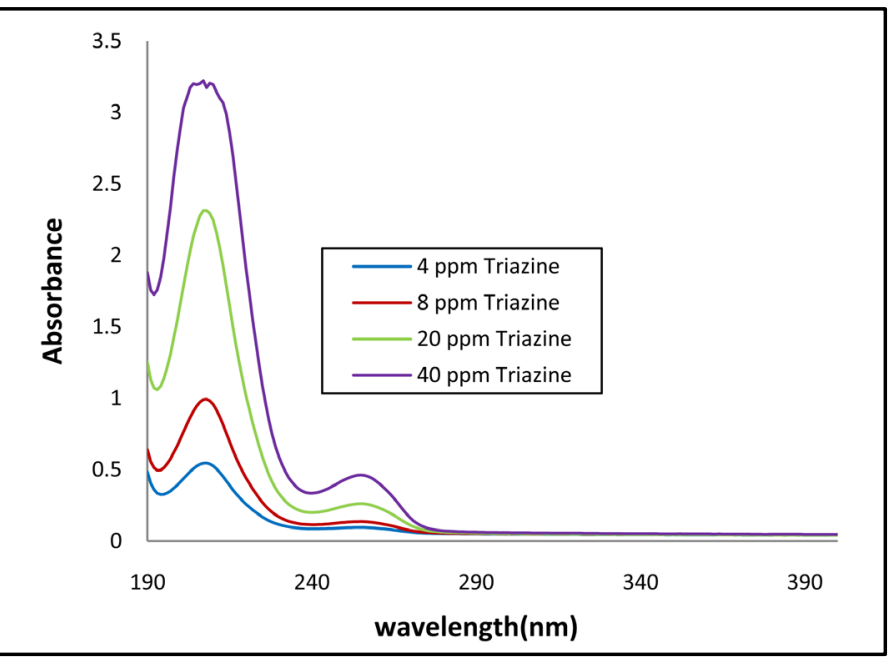

(a)

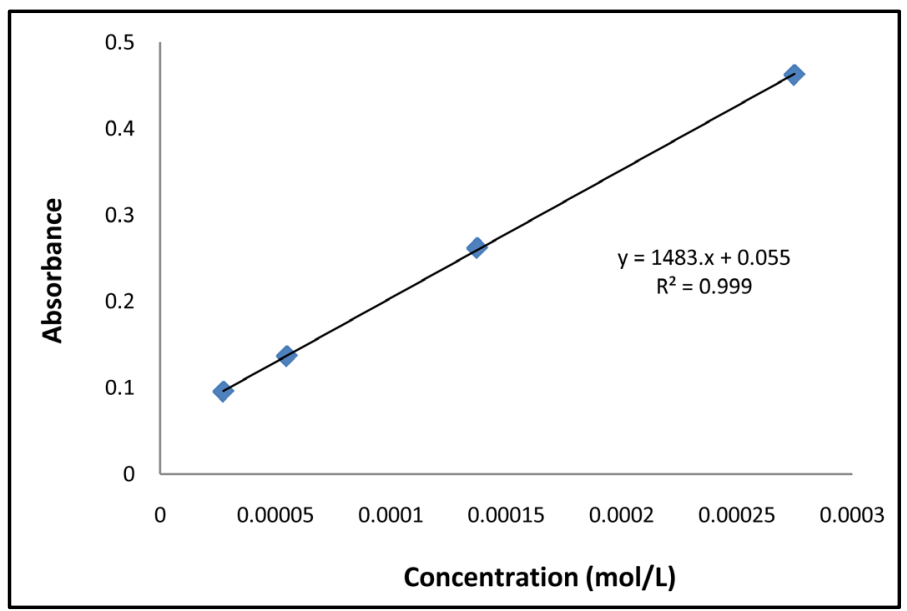

(b)

Figure 2. (a) UV-Visible spectra of triazine in water; (b) Calibration curve at $\lambda=255 \mathrm{~nm}$.

portion of UV light emitted by the UV-L lamp at $254 \mathrm{~nm}$ can be absorbed by triazine molecules. This method was used to measure the concentration of 2-chloro-4,6,-diamino-1,3,5-triazine during the treatment of aqueous solutions containing $40 \mathrm{ppm}$ of triazine herbicide at $\mathrm{pH} 3$ by Fenton, photo-Fenton and $\mathrm{UV} / \mathrm{H}_{2} \mathrm{O}_{2}$ processes as a function of time using $4000 \mathrm{mg} / \mathrm{L} \mathrm{H}_{2} \mathrm{O}_{2}$ in absence and presence of $5 \mathrm{mg} \mathrm{Fe}{ }^{2+} / \mathrm{L}$ and by irradiation of $\mathrm{UV}$ light or not. The results given in Figure 3, showed that the concentration of 2-chloro-4,6-diamino-1,3,5-triazine decreases during the treatment which indicates the degradation of the triazine herbicide by Fenton, photo-Fenton photolysis $\mathrm{UV} / \mathrm{H}_{2} \mathrm{O}_{2}$. It is also clear that the degradation of the triazine herbicide by photo-Fenton is more rapid and effective than by Fenton and $\mathrm{UV} / \mathrm{H}_{2} \mathrm{O}_{2}$ processes. This can be explained by the supplementary hydroxyls radicals produced by catalytic as shown in Equation (1) and photo-decomposition of $\mathrm{H}_{2} \mathrm{O}_{2}$ as shown in Equation (2).

However, this analytical method cannot inform about the transformation of the triazine herbicide and the nature of by products and intermediates formed. Taking into account the fact that the treatment of 2-chloro-4,6diamino-1,3,5-triazine by photo-Fenton processaimsto completely transforming this compound into $\mathrm{CO}_{2}, \mathrm{H}_{2} \mathrm{O}$, $\mathrm{Cl}^{-}$and $\mathrm{NO}_{3}^{-}$(or $\mathrm{NH}_{4}^{+}$), it is necessary to optimize the doses of chemicals and the nature of the UV light required to reach the goal. The experimental parameters studied were initial $\mathrm{pH}, \mathrm{H}_{2} \mathrm{O}_{2}$ concentration, ferrous iron dose, triazine concentration and UV light. The optimization of these parameters will achieve high yields of mineralization and reduce the cost of treatment. The mineralization of organic pollutants was followed by measure- 


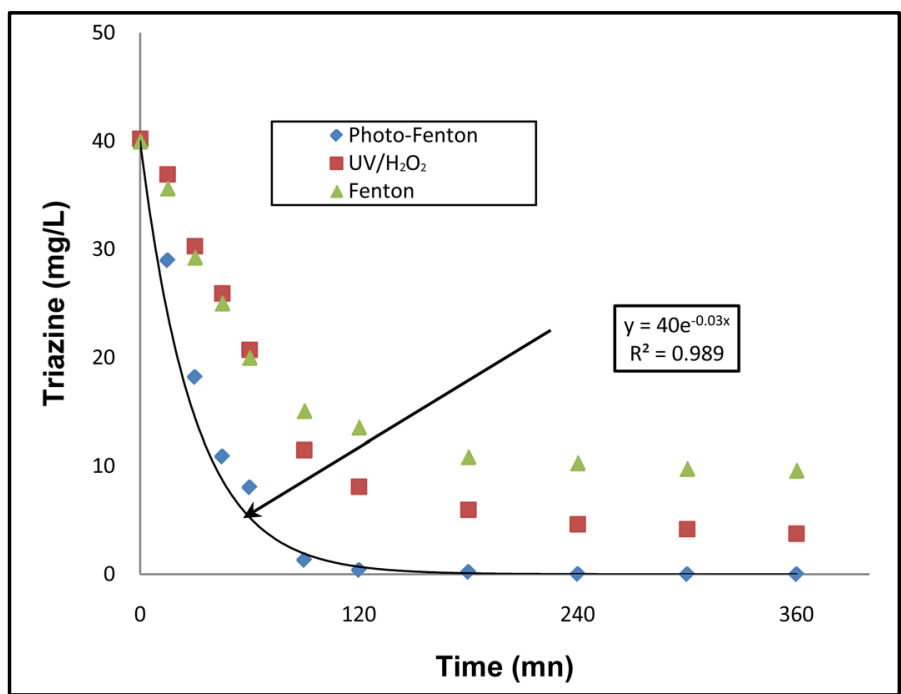

Figure 3. Changes of triazine concentration with time during the treatment of aqueous solutions containing $40 \mathrm{mg} / \mathrm{L}$ triazine using Fenton, photo-Fenton and $\mathrm{UV} / \mathrm{H}_{2} \mathrm{O}_{2}$. Experimental conditions: $4000 \mathrm{mg} / \mathrm{L} \mathrm{H}_{2} \mathrm{O}_{2}$, $5 \mathrm{mg} / \mathrm{L} \mathrm{Fe}^{2+}$, UV irradiation with UV-L lamp $(\lambda=254 \mathrm{~nm}), 300 \mathrm{rpm}$.

ing the chloride, nitrite and nitrate ions formed during the treatment by ion chromatography, the analysis of total organic carbon TOC and Kjeldahl nitrogen TKN.

\subsection{Influence of the Experimental Conditions on the Efficiency of the Degradation of 2-Chloro-4,6-diamino-1,3,5-triazine by Photo-Fenton Process}

\subsubsection{Influence of Initial pH}

Several authors have demonstrated that optimal $\mathrm{pH}$ for the production of hydroxyl radicals by the photo-Fenton process must be between 3 and 5 [34]-[36]. The $\mathrm{pH}$ is an important parameter that affects the efficiency of photo-Fenton process. The influence of the initial $\mathrm{pH}$ on the treatment of aqueous solutions containing $40 \mathrm{mg} / \mathrm{L}$ triazine by the photo-Fenton process was evaluated at different initial $\mathrm{pH}$ values ranging from 3.0 to 9.0 using $4000 \mathrm{mg} / \mathrm{L} \mathrm{H}_{2} \mathrm{O}_{2}, 5 \mathrm{mg} / \mathrm{L} \mathrm{Fe}^{2+}$ and room temperature. Figure 4 presents the changes of chloride ions concentration as function of time during the degradation of 2-chloro-4,6-diamino-1,3,5-triazine by photo-Fenton process at different initial $\mathrm{pH}$ values. The results presented in Figure 4 show that chloride ions released from the beginning of treatment for all values of initial $\mathrm{pH}$ studied here. In addition, the concentration of chloride ion undergoes a rapid and linear increase with time, and thenit reaches a plateau after $180 \mathrm{~min}$ of treatment. Theoretically, if all chlorine atoms are released as chloride ions during the treatment of $40 \mathrm{mg} / \mathrm{L}(0.275 \mathrm{mM})$ triazine, the maximum concentration of chloride ions should be equal to $9.75 \mathrm{mg} / \mathrm{L}$. As shown in Figure 4, the amount of chloride ions measured at the end of treatment does not reach the theoretical value of $9.75 \mathrm{mg} / \mathrm{L}$ for all initial pH studied. This could be due to mass transfer limitation when the concentration of triazine becomes low and to higher affinity of the intermediates formed compared to the starting material relative to hydroxyl radicals, or the transformation of chloride ions into hypochlorous acid $(\mathrm{ClOH})$ or hypochlorite acid $\left(\mathrm{ClO}^{-}\right)$depending on the $\mathrm{pH}$ of the medium by oxidation of the hydroxyl radicals (Tatapudi et al., 1994).However, the treatment of aqueous solutions containing $40 \mathrm{mg} / \mathrm{L}$ triazine by photo-Fenton process resulted in the release of $8.0 \mathrm{mg} \mathrm{Cl}^{-} / \mathrm{L}$ at $\mathrm{pH} 3.0$, $5.6 \mathrm{mg} \mathrm{Cl}^{-} / \mathrm{L}$ at natural $\mathrm{pH}(\mathrm{pH}=5.3), 6.0 \mathrm{mg} \mathrm{Cl}^{-} / \mathrm{L}$ at $\mathrm{pH} 7.0$ and 9.0 , respectively. This indicates that more than $80 \%$ of chlorine atoms were released at $\mathrm{pH} 3.0$; while, the yield of chloride ions formation is between 57 and $62 \%$ for other initial $\mathrm{pH}$ studied.

Figure 5 presents the influence of initial $\mathrm{pH}$ on the formation of nitrates ions as a function of time during photo-Fenton treatment of aqueous solutions containing $40 \mathrm{mg} / \mathrm{L}$ triazine (2-chloro-4,6-diamino-1,3,5-triazine). These results show that the treatment of aqueous solutions of triazine by photo-Fenton process leads to the formation of nitrate ions at all initial $\mathrm{pH}$ values studied. Also, the concentration of nitrite ions during the treatment was measured; but only small amounts of nitrite ions (donot exceed $0.2 \mathrm{mg} / \mathrm{L}$ ) were detected. These results in- 


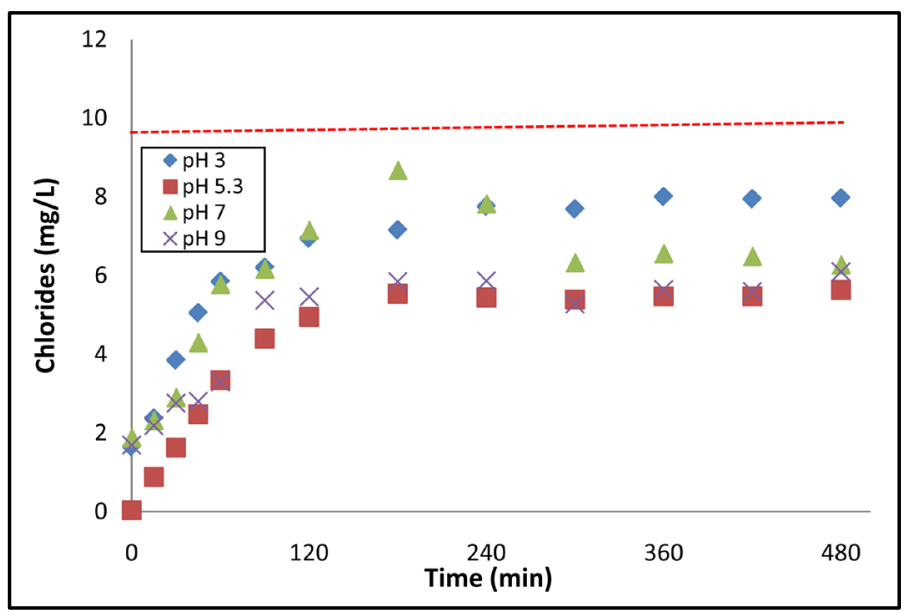

Figure 4. Influence of initial $\mathrm{pH}$ on the formation of chlorides during photo-Fenton treatment of aqueous solutions containing $40 \mathrm{mg} / \mathrm{L}$ triazine. Experimental Conditions: $4000 \mathrm{mg} / \mathrm{L} \mathrm{H}_{2} \mathrm{O}_{2}, 5 \mathrm{mgFe}^{2+} / \mathrm{L}$, UV-L (40 W) irradiation, pH 3 - 9, Room temperature $\left(23-25^{\circ} \mathrm{C}\right), 300 \mathrm{rpm}$.

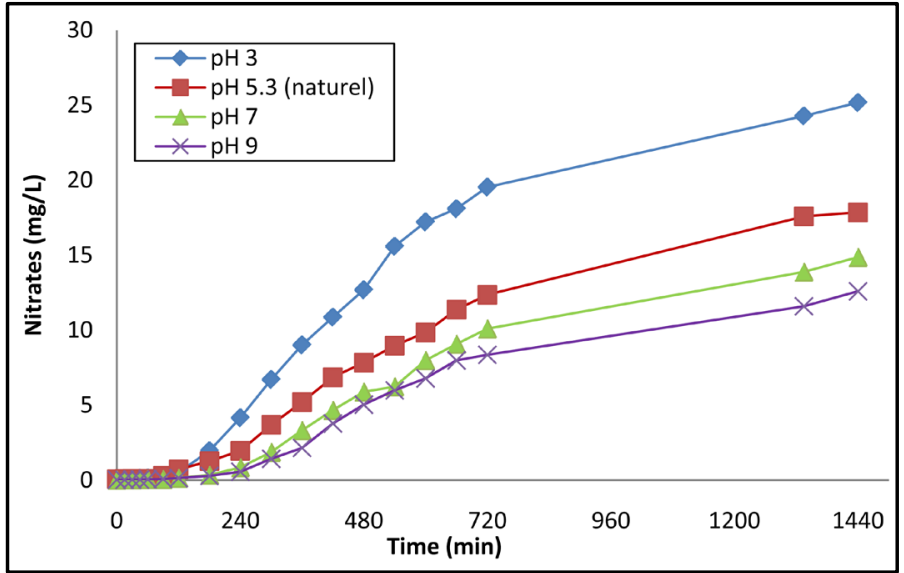

Figure 5. Influence of initial $\mathrm{pH}$ on the formation of nitrates during photo-Fenton treatment of aqueous solutions containing $40 \mathrm{mg} / \mathrm{L}$ triazine. Experimental Conditions: $4000 \mathrm{mg} / \mathrm{L} \mathrm{H}_{2} \mathrm{O}_{2}, 5 \mathrm{mg} \mathrm{Fe}{ }^{2+} / \mathrm{L}$, UV-L (40 W) irradiation, $\mathrm{pH} 3-9$, Room temperature $\left(23^{\circ} \mathrm{C}-25^{\circ} \mathrm{C}\right), 300 \mathrm{rpm}$.

dicate that part of the organic nitrogen of 2-chloro-4,6-diamino-1,3,5-triazine was released in the form of nitrates. It should be noted that if all organic nitrogen is released in the form of nitrate ions during the treatment of 40 $\mathrm{mg} / \mathrm{L}(0.275 \mathrm{mM})$ triazine, the theoretical maximum concentration of nitrate ions is equal to about $85.25 \mathrm{mg} / \mathrm{L}$; but all initial $\mathrm{pH}$ values tested did not result in the formation of the theoretical concentration of $85.25 \mathrm{mg} / \mathrm{L}$. However, increasing the $\mathrm{pH}$ from 3.0 to 9.0 has decreased the amount of nitrate ions formed during the treatment. Amounts of nitrate ions from $17.8 \mathrm{mg} / \mathrm{L}, 14.9 \mathrm{mg} / \mathrm{L}$ and $12.6 \mathrm{mg} / \mathrm{L}$, respectively, were measured at $\mathrm{pH} 5.3$ (natural), 7.0 and 9.0 after 24 hours of treatment. The highest amount of nitrate ions $(25.2 \mathrm{mg} / \mathrm{L})$ was measured at $\mathrm{pH} 3.0$ after 24 hours of treatment, which corresponds to about $30 \%$ of the theoretical nitrate concentration. These results indicate that the release of organic nitrogen of 2-chloro-4,6-diamino-1,3,5-triazine as nitrate ions involves several steps, consumes large amounts of hydroxyl radicals and absorbs important portion of UV Light. The results of Figure 5 show that the photo-Fenton process failed to transform all organic nitrogen into nitrate or nitrite ions.

It can be concluded that:

- A pH 3.0 is optimal to achieve the highest yields of degradation of 2-chloro-4,6-diamino-1,3,5-triazine photo-Fenton process in terms of release of chlorine atoms as chloride ions and organic nitrogen as nitrate ions. 
This could be due mainly to two factors: The first is related to the catalytic decomposition of hydrogen peroxide by ferrous ions to produce hydroxyl radicals which are accelerated in acidic, whereas the second phenomenon concerns the ionic or molecular characteristics of triazine which is probably in the cationic form at pH 3.0 which facilitates the attack by hydroxyl radicals.

- Increasing $\mathrm{pH}$ to values higher than 3.0, during photo-Fenton treatment of aqueous solutions containing 40 $\mathrm{mg} / \mathrm{L}$ triazine with $4000 \mathrm{mg} \mathrm{H} \mathrm{H}_{2} \mathrm{O}_{2} / \mathrm{L}, 5 \mathrm{mg} \mathrm{Fe}{ }^{2+} / \mathrm{L}$ and UV-L irradiation, did not enhance the formation of chloride ions; in contrast, it decreases the formation of nitrates. This can be due to precipitation of ferric ions at neutral and alkaline $\mathrm{pH}$ which limits the regeneration of ferrous iron catalyst and then decreases the efficiency of the process

- The degradation of 2-chloro-4,6-diamino-1,3,5-triazine by the photo-Fenton process at $\mathrm{pH} 3.0$ results in the release of about $80 \%$ of chlorine atoms as chlorides and $30 \%$ of organic nitrogen as nitrate ions.

\subsubsection{Influence of the Initial Concentration of $\mathrm{Fe}^{2+}$}

The ferrous ions used as the catalyst for the decomposition of hydrogen peroxide according to the reaction Fenton to form of ferric ions (Equation (1)). These ions are excellent catalyst and a small catalytic amount may be sufficient to decompose $\mathrm{H}_{2} \mathrm{O}_{2}$ efficiently into hydroxyl radical $\mathrm{HO}^{\circ}$. High doses of ferrous ions can lead to the formation of insoluble hydroxo- and organo-ferriccomplexes. To study the influence of dose of $\mathrm{Fe}^{2+}$ ions on the efficiency of the treatment of aqueous solutions ( $\mathrm{pH} 3.0$ ) containing $40 \mathrm{mg} / \mathrm{L}$ of 2-chloro-4,6-diamino-1,3,5-triazine by photo-Fenton process, the concentration of $\mathrm{H}_{2} \mathrm{O}_{2}$ was fixed to $4000 \mathrm{mg} / \mathrm{L}$, and dose of $\mathrm{Fe}^{2+}$ was varied between 0 and $20 \mathrm{mg} / \mathrm{L}$ at room temperature. Figure 6 and Figure 7 present the changes of concentrations of chloride and nitrate ions as a function of time during the degradation of 2-chloro-4,6-diamino-1,3,5-triazine by photo-Fenton process for different doses of $\mathrm{Fe}^{2+}$ ions in the range $0-20 \mathrm{mg} / \mathrm{L}$. Figure 7 shows a abrupt increase of chloride ions at the beginning of the treatment, and then it becomes eventually constant after four hours treatment. Contrarily, Figure 8 shows that the formation of nitrate ions does not start from the beginning of the treatment, but after two hours of treatment nitrate ions start to form. The concentration of nitrate ions undergoes a continuous and slow increase for about 12 hours' treatment. It should be noted also that for relatively high amounts of ferrous ions, chloride and nitrate ions concentrations are lower than those measured without addition of catalyst. These results indicate that the release of chloride ions is faster that the formation of nitrate ions during the treatment of 2-chloro-4,6-diamino-1,3,5-triazine by photo-Fenton process. However, these results clearly confirm that the amounts of chloride and nitrate ions generated during the treatment depends largely on the dose of ferrous ions: In absence of ferrous ions, photolysis $\mathrm{UV} / \mathrm{H}_{2} \mathrm{O}_{2}$ resulted in the formation of $6.5 \mathrm{mg} \mathrm{Cl} / \mathrm{L}$ and $17.3 \mathrm{mg} \mathrm{NO}-$ /L corresponding to the release of $67 \%$ and $20.4 \%$ of chlorine and nitrogen atoms of 2-chloro4,6-diamino-1,3,5-triazine. The addition of ferrous ions dose of $5 \mathrm{mg} / \mathrm{L}$ has improved yields of formation of chloride and nitrate ions to $8.0 \mathrm{mg} \mathrm{Cl}^{-} / \mathrm{L}$ and $25.2 \mathrm{mg} \mathrm{NO}-/ \mathrm{L}$. However, the addition of a dose of $\mathrm{Fe}^{2+}$ greater than $5 \mathrm{mg} / \mathrm{L}$ decreases the efficiency of the degradation of 2-chloro-4,6-diamino-1,3,5-triazine by photo-Fenton process in terms of chloride and nitrate ions formation. $20 \mathrm{mg} / \mathrm{L} \mathrm{Fe}^{2+}$ ions result in the formation of $4.2 \mathrm{mg} \mathrm{Cl} / \mathrm{L}$ and $17.3 \mathrm{mg} \mathrm{NO} / \mathrm{L}$. A dose of $\mathrm{Fe}^{2+}$ higher than $5 \mathrm{mg} / \mathrm{L}$, does not have any significant influence on the formation of nitrate ions. The results obtained in this work are not in agreement with those mentioned in literature by many authors about the influence of $\mathrm{Fe}^{2+}$ ions on the efficiency of photo-Fenton process. Several research studies showed that increasing the dose of ferrous ions resulted into more efficient processes, since $\mathrm{Fe}^{2+}$ ions are found in sufficient amount when high doses are added which causes the acceleration of production radical hydroxyls by reaction Fenton as follows:

$$
\mathrm{H}_{2} \mathrm{O}_{2}+\mathrm{Fe}^{2+} \rightarrow \mathrm{Fe}^{3+}+\mathrm{HO}^{-}+\mathrm{HO}^{\bullet}
$$

To explain these results, some basic concepts of coordination chemistry and the results reported in the literature should be taken into account. Szumera et al., [37] mentioned that $\mathrm{Fe}^{2+}$ and $\mathrm{Fe}^{3+}$ can form complexes with striazines with stability constants between $10^{3}$ and $10^{5}$. Gun et al., [38] have also described a photometric method of analysis of $\mathrm{Fe}^{3+}$ ions by complexation of $\mathrm{Fe}^{3+}$ by the bis-(hydroxyamino)-triazines. Based on these results, it seems that $\mathrm{Fe}^{2+}$ ions initially added and $\mathrm{Fe}^{3+}$ ions formed during the treatment may also form stable complexes with 2-chloro-4,6-diamino-1,3,5-triazine or one of its degradation intermediates. The formation of stabile $\mathrm{Fe}(\mathrm{II})$-triazine complexes reduce the number of free triazine molecules available to react with hydroxyl radicals; while $\mathrm{Fe}(\mathrm{III})$-triazine complexes consume large amount of UV light to dissociate into $\mathrm{Fe}^{3+}$ and free triazine molecules. Triazine molecule is a tridentate ligand, the formation of Fe(II)-triazine requires two moles of triazine 


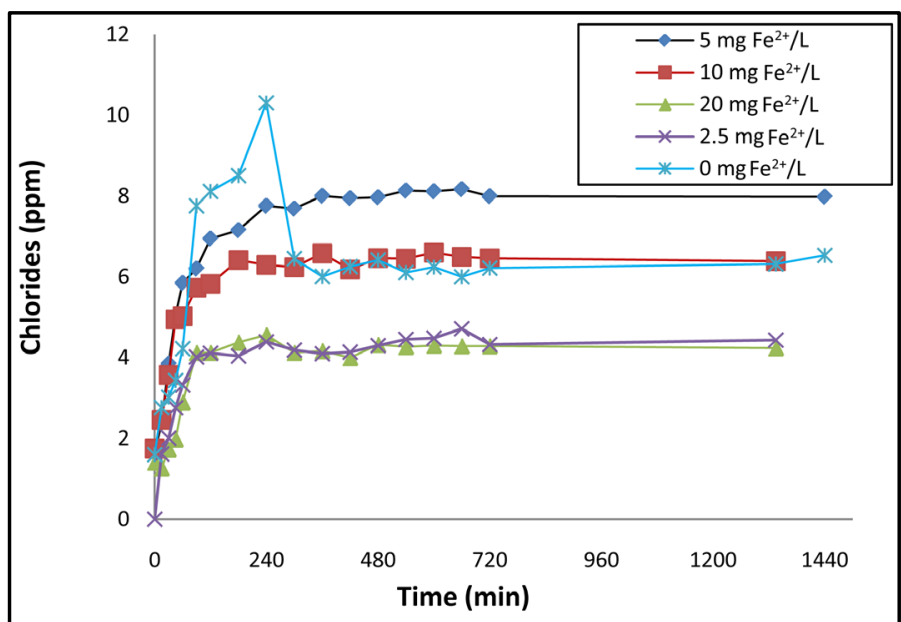

Figure 6. Influence of ferrous iron dose on the formation of chlorides during photo-Fenton treatment of aqueous solutions containing $40 \mathrm{mg} / \mathrm{L}$ triazine. Experimental Conditions: $4000 \mathrm{mg} / \mathrm{L} \mathrm{H}_{2} \mathrm{O}_{2}, 0-20 \mathrm{mg} \mathrm{Fe}^{2+} / \mathrm{L}$, UV-L $(40 \mathrm{~W})$ irradiation, $\mathrm{pH} 3$, Room temperature $\left(23^{\circ} \mathrm{C}-25^{\circ} \mathrm{C}\right), 300 \mathrm{rpm}$.

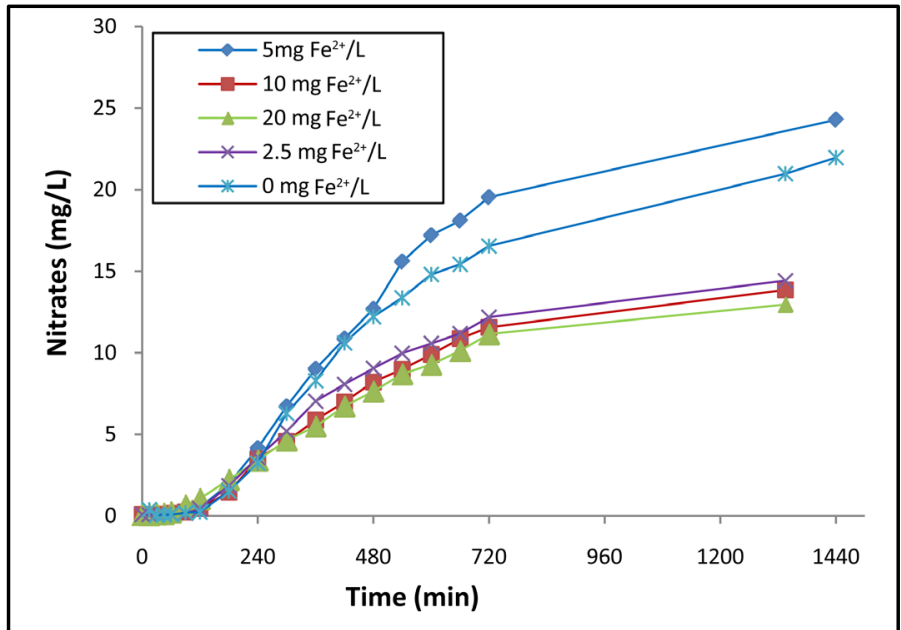

Figure 7. Influence of ferrous iron dose on the formation of nitrates during photo-Fenton treatment of aqueous solutions containing $40 \mathrm{mg} / \mathrm{L}$ triazine. Experimental conditions: $4000 \mathrm{mg} / \mathrm{L} \mathrm{H}_{2} \mathrm{O}_{2}, 0$ - $20 \mathrm{mg} \mathrm{Fe}^{2+} / \mathrm{L}$, UV-L (40 W) irradiation, $\mathrm{pH}$, Room temperature $\left(23^{\circ} \mathrm{C}-25^{\circ} \mathrm{C}\right), 300 \mathrm{rpm}$.

per mole of $\mathrm{Fe}^{2+}$. It is inferred that to complex all herbicide molecules initially contained in the solution of 40 $\mathrm{mg} / \mathrm{L}(0.275 \mathrm{mM})$ minimum $0.1375 \mathrm{mM} \mathrm{Fe}{ }^{2+}$ must be added which corresponds to $7.7 \mathrm{mg} \mathrm{Fe} \mathrm{F}^{2+} / \mathrm{L}$. It is then possible that for $\mathrm{Fe}^{2+}$ doses $<7.7 \mathrm{mg} \mathrm{Fe}{ }^{2+} / \mathrm{L}, \mathrm{Fe}^{2+}$ ions as the triazine molecules are not completely complex. For doses $>7.7 \mathrm{mg} \mathrm{Fe} \mathrm{F}^{2+} / \mathrm{L}, \mathrm{Fe}^{2+}$ ions are in excess in the solution, which shifts the equilibrium of formation of $\mathrm{Fe}(\mathrm{II})$-triazine to the right and therefore all triazine molecules are complex which makes their attack by hydroxyl radicals very difficult. In addition, if high doses of $\mathrm{Fe}^{2+}$ are added, the regeneration of the catalyst $\left(\mathrm{Fe}^{2+}\right.$ ions) from $\mathrm{Fe}^{3+}$ ions becomes slow due to the precipitation of ferric hydroxide $\mathrm{Fe}(\mathrm{OH})_{3}$. For these reasons, increasing the dose of $\mathrm{Fe}^{2+}$ ions has negatively influence the degradation of the herbicide studied in contrast to what is reported in the literature. A dose of $5 \mathrm{mg} \mathrm{Fe} e^{2+} / \mathrm{L}$ was optimal to form the highest chloride and nitrate amounts during photo-Fenton treatment of aqueous solutions containing $40 \mathrm{mg} / \mathrm{L}$ triazine at $\mathrm{pH} 3.0$ using $4000 \mathrm{mg} \mathrm{H}_{2} \mathrm{O}_{2} / \mathrm{L}$ and UV-L irradiation. This can be explained by 1) lower ferrous doses than $5 \mathrm{mg} \mathrm{Fe} / \mathrm{L}$ are not sufficient to enhance the production of hydroxyls radicals, 2) the formation of stable triazine-ferric iron complexes that consume UV light to decompose which inhibits the regeneration of the catalyst and precipitation of ferric iron and 
then lower the amount of ferrous iron catalyst in the media.

\subsubsection{Influence of the $\mathrm{H}_{2} \mathrm{O}_{2}$ Concentration}

The performance of photo-Fenton process is mainly related to the production of hydroxyl radicals by chemical and photochemical decomposition of hydrogen peroxide. Hydrogen peroxide is the main source of hydroxyl radicals although little amount of $\mathrm{HO}^{\bullet}$ can be formed by water photolysis. Consequently, the initial concentration of $\mathrm{H}_{2} \mathrm{O}_{2}$ is considered as a fundamental factor that limits the production of hydroxyl radicals during the treatment by the photo-Fenton process [19] [21]. To study the effect of the concentration of hydrogen peroxide on the formation of chloride and nitrate ions during photo-Fenton treatment of aqueous solutions containing 40 $\mathrm{mg} / \mathrm{L}$ triazine at $\mathrm{pH} 3.0,\left[\mathrm{H}_{2} \mathrm{O}_{2}\right] /\left[\mathrm{Fe}^{2+}\right]$ mass ratio was kept constant and equal 800 and $\mathrm{UV}$ irradiation was performed by low pressure mercury lamp (UV-L) emitting UV light at a wavelength of $254 \mathrm{~nm}$. Figure 8 and Figure 9 present the changes of concentration of chloride and nitrate ions with time during the degradation of 2chloro-4,6-diamino-1,3,5-triazine by photo-Fenton process using 2000, 4000 and $6000 \mathrm{mg} / \mathrm{L}$ of $\mathrm{H}_{2} \mathrm{O}_{2}$. The results obtained show that the increase of the initial concentration of $\mathrm{H}_{2} \mathrm{O}_{2}$ from $2000 \mathrm{mg} / \mathrm{L}$ to $4000 \mathrm{mg} / \mathrm{L}$ increases both the rate and the yield of formation of chloride and nitrate ions. It should be noted that no nitrate formation was observed when $2000 \mathrm{mg} / \mathrm{L} \mathrm{H}_{2} \mathrm{O}_{2}$ was used while $25.2 \mathrm{mg} / \mathrm{L}$ nitrate was measured using $4000 \mathrm{mg}$ $\mathrm{H}_{2} \mathrm{O}_{2} / \mathrm{L}$. These results can be interpreted by the fact that increasing the concentration of $\mathrm{H}_{2} \mathrm{O}_{2}$ and $\mathrm{Fe}^{2+}$ in the medium enhances the production of hydroxyl radicals $\mathrm{HO}^{\bullet}$ and consequently accelerates the release of chlorine and nitrogen atoms of 2-chloro-4,6-diamino-1,3,5-triazine. However, when the initial concentration of $\mathrm{H}_{2} \mathrm{O}_{2}$ increases from $4000 \mathrm{mg} / \mathrm{L}$ to $6000 \mathrm{mg} / \mathrm{L}$, different results were obtained. Indeed, the concentration of chloride ions increases rapidly at the beginning of the treatment, to reach a maximum of about $6.5 \mathrm{mg} / \mathrm{L}$ at $90 \mathrm{~min}$, and then drops sharply and completely disappears after $300 \mathrm{~min}$. Also, very low amounts of nitrate were measured during the treatment of 2-chloro-4,6-diamino-1,3,5-triazine by photo-Fenton process using $6000 \mathrm{mg}_{2} \mathrm{O}_{2} / \mathrm{L}$ and $7.5 \mathrm{mg} \mathrm{Fe} e^{2+} / \mathrm{L}$. These results indicate that chlorine atoms were released as chloride ions from the beginning of treatment, but the later undergo rapid oxidation into active chlorine ( $\mathrm{HClO}$ and $\mathrm{ClO}^{-}$) by hydroxyl radicals formed in large excess when high concentrations of $\mathrm{H}_{2} \mathrm{O}_{2}$ and $\mathrm{Fe}^{2+}$ are used according to the reaction below:

$$
\begin{aligned}
2 \mathrm{Cl}^{-} & \rightarrow \mathrm{Cl}_{2}+2 \mathrm{e} \\
\mathrm{Cl}_{2}+\mathrm{H}_{2} \mathrm{O} & \rightarrow \mathrm{HOCl}+\mathrm{H}^{+}+\mathrm{Cl}^{-} \\
\mathrm{HOCl} & \leftrightarrow \mathrm{H}^{+}+\mathrm{OCl}^{-}
\end{aligned}
$$

The fact that low amounts of nitrates were detected for the highest concentrations of $\mathrm{H}_{2} \mathrm{O}_{2}$ and $\mathrm{Fe}^{2+}$ does not indicate that there is no release of nitrogen as in the case of low concentrations of $\mathrm{H}_{2} \mathrm{O}_{2}$ and $\mathrm{Fe}^{2+}$, but the nitrogen released from the triazine herbicide molecule can be rapidly transformed into ammonium ions by photochemical reduction of nitrite and nitrate by $\mathrm{Fe}^{2+}$ ions and UV irradiation (Fanning, 2000). Furthermore, the results of TOC and TKN analyses of samples taken during the treatment containing $40 \mathrm{mg} / \mathrm{L}$ triazine by photoFenton process using $6000 \mathrm{mg} / \mathrm{L} \mathrm{H}_{2} \mathrm{O}_{2}$ and $7.5 \mathrm{mg} \mathrm{Fe} e^{2+} / \mathrm{L}$ (Table 1) showed that TOC does not change during photo-Fenton experiment. This indicates that photo-Fenton process was unable to open the triazine ring even with $\mathrm{H}_{2} \mathrm{O}_{2}$ concentration greater than $4000 \mathrm{mg} / \mathrm{L}$. TKN results showed that photo-Fenton process can release up to $40 \%$ of the nitrogen of 2-chloro-4,6-diamino-1,3,5-triazine representing the nitrogen of the amino groups (- $\left.\mathrm{NH}_{2}\right)$ oftriazine ring. For low concentrations of $\mathrm{H}_{2} \mathrm{O}_{2}(\leq 2000 \mathrm{mg} / \mathrm{L})$, hydroxyl radicals generated by the chemical decomposition of hydrogen peroxideby the ferrous ions and its photochemical decomposition by UV irradiation are not sufficient to release all the chlorine atoms and even small part of organic nitrogen of 2-chloro-4,6diamino-1,3,5-triazine. Also, higher concentrations of $\mathrm{H}_{2} \mathrm{O}_{2}$ than $4000 \mathrm{mg} / \mathrm{L}$ did not achieve higher nitrate formation than that obtained when $4000 \mathrm{mg} \mathrm{H}_{2} \mathrm{O}_{2} / \mathrm{L}$ was used. This result can be explained by 1 ) accelerating the decomposition of $\mathrm{H}_{2} \mathrm{O}_{2}$ into water and oxygen; 2) formation of triazine-ferric iron complexes which leads to lower quantum yield for hydrogen peroxide decomposition; 3) competition between triazine molecules and its intermediates such as chloride ions towards hydroxyl radicals with formation of chlorine species.

Also, UV irradiation using UV-L lamp was found to be more efficient than UV-M lamp which is related to the quantum yield of $\mathrm{H}_{2} \mathrm{O}_{2}$ photodecomposition that absorbs UV light between 200 and $260 \mathrm{~nm}$ and then UV irradiation at $254 \mathrm{~nm}$ achieves homolytic rupture of O-O bonds with a quantum yield close to unit.

$$
\mathrm{H}_{2} \mathrm{O}_{2}+h v \rightleftarrows 2 \mathrm{HO}^{\bullet}
$$




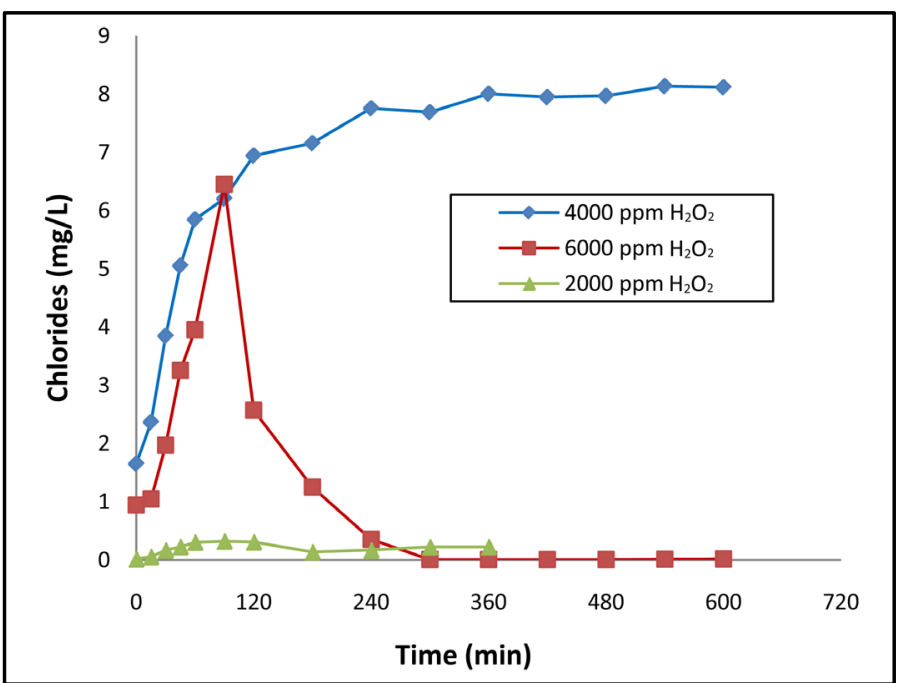

Figure 8. Influence of $\mathrm{H}_{2} \mathrm{O}_{2}$ concentration on the formation of chloride ions during photo-Fenton treatment of aqueous solutions containing 40 $\mathrm{mg} / \mathrm{L}$ triazine. Experimental Conditions: 2000 - $6000 \mathrm{mg} / \mathrm{L} \mathrm{H}_{2} \mathrm{O}_{2}$, mass ratio $\left[\mathrm{H}_{2} \mathrm{O}_{2}\right] /\left[\mathrm{Fe}^{2+}\right]=800$, UV-L $(40 \mathrm{~W})$ irradiation, $\mathrm{pH} 3$, Room temperature $\left(23^{\circ} \mathrm{C}-25^{\circ} \mathrm{C}\right), 300 \mathrm{rpm}$.

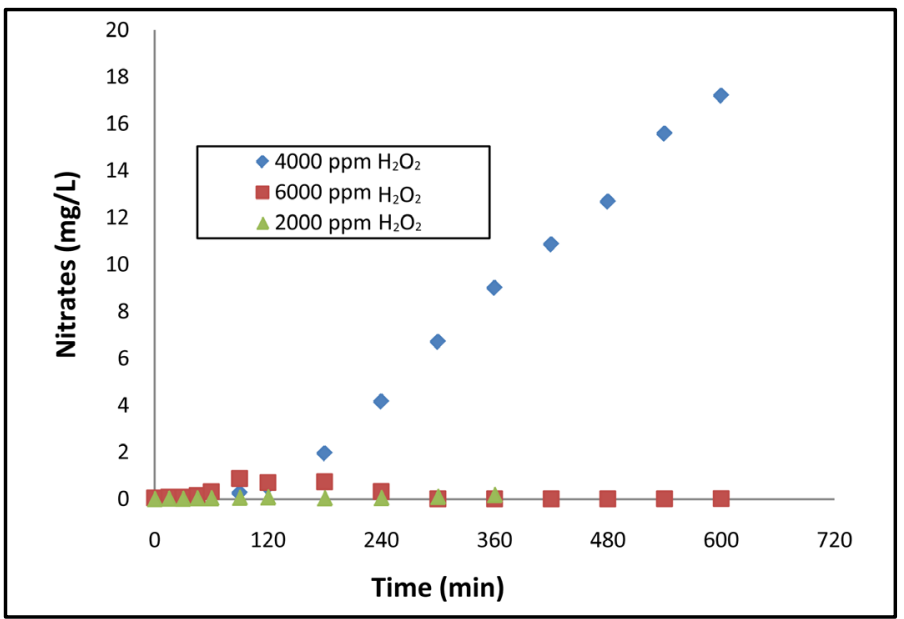

Figure 9. Influence of ferrous iron dose on the formation of nitrates during photo-Fenton treatment of aqueous solutions containing $40 \mathrm{mg} / \mathrm{L}$ triazine. Experimental conditions: $4000 \mathrm{mg} / \mathrm{L} \mathrm{H}_{2} \mathrm{O}_{2}, 0-20 \mathrm{mg} \mathrm{Fe} / \mathrm{L}$, UV-L (40 W) irradiation, $\mathrm{pH}$, Room temperature $\left(23^{\circ} \mathrm{C}-25^{\circ} \mathrm{C}\right), 300 \mathrm{rpm}$.

$$
\begin{gathered}
\mathrm{H}_{2} \mathrm{O}_{2}+\mathrm{HO}^{\bullet} \rightleftarrows \mathrm{HO}_{2}^{\bullet}+\mathrm{H}_{2} \mathrm{O} \\
2 \mathrm{H}_{2} \mathrm{O}_{2} \rightleftarrows \mathrm{O}_{2}+2 \mathrm{H}_{2} \mathrm{O}
\end{gathered}
$$

\subsubsection{Influence of the Variation of Concentration of 2-Chloro-4,6-diamino-1,3,5-triazine}

The initial organic matter has an important influence on the efficiency of advanced oxidation processes. For this reason we decided to also study the influence of the concentration of 2-chloro-4,6-diamino-1,3,5-triazine on the efficiency of treatment by photo-Fenton process. To study the influence of this parameter, the mass ratio $\left[\mathrm{H}_{2} \mathrm{O}_{2}\right] /$ $\left[\mathrm{Fe}^{2+}\right]$ and $\left[\mathrm{H}_{2} \mathrm{O}_{2}\right] /[$ [riazine] are maintained constant and equal to 100 and 800 respectively. Figure 10 and Figure 11 present the changes of concentrations of chloride and nitrateions with time during the treatment of aqueous solutions containing different concentrations of 2-chloro-4,6-diamino-1,3,5-triazine in the range of 20 
Table 1. TOC and TKN analysis results of 2-Chloro-4,6-diamino-1,3,5-triazine degradation using photo-Fenton process (UV$\left.\mathrm{L} / \mathrm{H}_{2} \mathrm{O}_{2} / \mathrm{Fe}^{2+}\right)$. Experimental conditions: $40 \mathrm{mg} / \mathrm{L}(0.275 \mathrm{mM})$ triazine, $7.5 \mathrm{mg} / \mathrm{L} \mathrm{Fe}{ }^{2+}, 6000 \mathrm{mg} / \mathrm{L} \mathrm{H}_{2} \mathrm{O}_{2}$, UV-L (40 W) irradiation, $\mathrm{pH} 3$, room temperature $\left(23^{\circ} \mathrm{C}-25^{\circ} \mathrm{C}\right), 300 \mathrm{rpm}$.

\begin{tabular}{ccc}
\hline Time (min) & TOC (mg C/L) & TKN (mg N/L) \\
\hline 0 & 9.65 & 19.84 \\
45 & 9.76 & 19.76 \\
90 & 9.32 & 20.14 \\
180 & 9.45 & 19.86 \\
300 & 9.81 & 20.24 \\
420 & 9.42 & 20.11 \\
660 & 9.64 & 20.06 \\
\hline
\end{tabular}

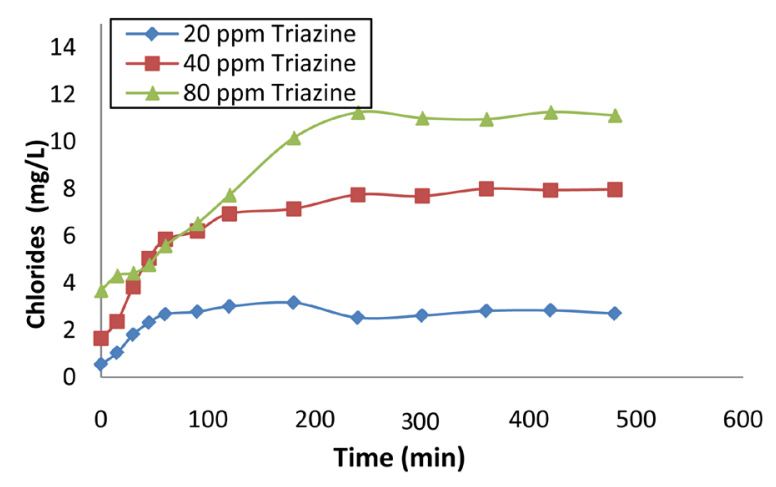

Figure 10. Influence of initial concentration of 2-chloro-4,6-diamino-1, 3,5-triazine on the formation of chlorides during the treatment by photo-Fenton process $\left(\mathrm{UV} / \mathrm{H}_{2} \mathrm{O}_{2} / \mathrm{Fe}^{2+}\right)$. Experimental Conditions: $20-80$ $\mathrm{mg} / \mathrm{L}$ of triazine, mass ratio $\left[\mathrm{H}_{2} \mathrm{O}_{2}\right] /[$ triazine $]=100,5 \mathrm{mg} \mathrm{Fe}^{2+} / \mathrm{L}, \mathrm{UV}-$ $\mathrm{L}(40 \mathrm{~W})$ irradiation, $\mathrm{pH} 3$, Room temperature, $300 \mathrm{rpm}$.

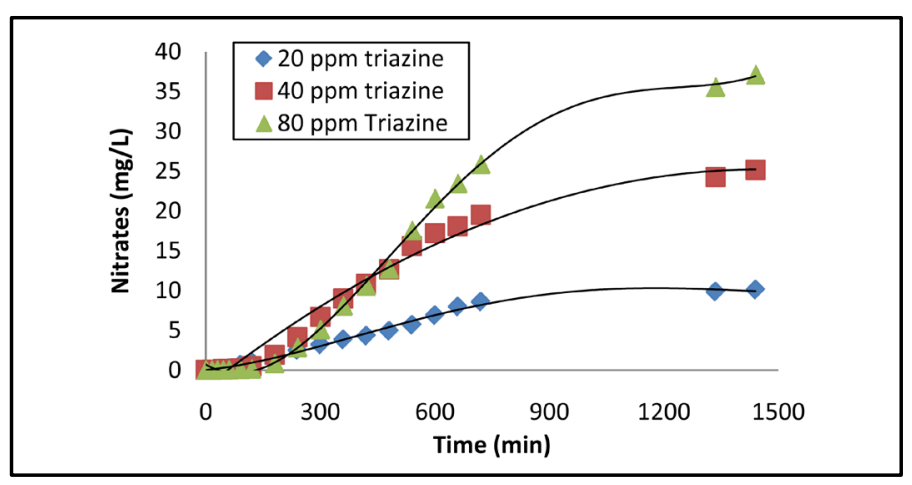

Figure 11. Influence of initial concentration of 2-chloro-4,6-diamino-1, 3,5-triazine on the formation of nitrates during the treatment by photoFenton process $\left(\mathrm{UV} / \mathrm{H}_{2} \mathrm{O}_{2} / \mathrm{Fe}^{2+}\right)$. Experimental Conditions: $20-80$ $\mathrm{mg} / \mathrm{L}$ of triazine, mass ratio $\left[\mathrm{H}_{2} \mathrm{O}_{2}\right] /[$ triazine $]=100,5 \mathrm{mg} \mathrm{Fe}^{2+} / \mathrm{L}, \mathrm{UV}-\mathrm{L}$ $(40 \mathrm{~W})$ irradiation, $\mathrm{pH} 3$, room temperature, $300 \mathrm{rpm}$.

to $80 \mathrm{mg} / \mathrm{L}$ by the photo-Fenton process at $\mathrm{pH}$ 3.0. Increasing the concentration of triazine leads to a significant increase in the amounts of chloride and nitrateions measured at the end of the treatment. The treatment of aqueous solutions containing $20 \mathrm{mg} / \mathrm{L}, 40 \mathrm{mg} / \mathrm{L}$ and $80 \mathrm{mg} / \mathrm{L}$ of triazine by the photo-Fenton process led to the 
formation of $2.7 \mathrm{mg} \mathrm{Cl}^{-} / \mathrm{L}$ and $10.1 \mathrm{mg} \mathrm{NO}_{3}^{-} / \mathrm{L}, 8 \mathrm{mg} \mathrm{Cl}^{-} / \mathrm{L}$ and $25.2 \mathrm{mg} \mathrm{NO}_{3}^{-} / \mathrm{L}$ and $11.1 \mathrm{mg} \mathrm{Cl}^{-} / \mathrm{L}$ and 37.1 $\mathrm{mg} \mathrm{NO}_{3}^{-} / \mathrm{L}$, respectively. Although the treatment of $80 \mathrm{mg} / \mathrm{L}$ of triazine by photo-Fenton process led to the formation of higher amounts of chloride and nitrate ions, the yield of formation of chloride and nitrate ions are lower than those obtained with $20 \mathrm{mg} / \mathrm{L}$ and $40 \mathrm{mg} / \mathrm{L}$ as shown in Figure 12. The treatment of $40 \mathrm{mg} / \mathrm{L}$ of 2chloro-4,6-diamino-1,3,5-triazine by photo-Fenton process gives the highest yields of formation of chloride and nitrate ions. For low concentrations of triazine, $\mathrm{H}_{2} \mathrm{O}_{2}$ and $\mathrm{Fe}^{2+}$, the collision of radicals $\mathrm{HO}^{\bullet}$ with free triazine molecules is limited by mass transfer. When the concentration of triazine increases, the concentrations of $\mathrm{H}_{2} \mathrm{O}_{2}$ and $\mathrm{Fe}^{2+}$ are also increased which improves the production of radicals $\mathrm{HO}^{\bullet}$ in the medium. These radicals react rapidly with free triazine molecules to release chlorineand nitrogen atoms as chloride as nitrate ions, respectively. The results obtained for higher concentrations of triazine than $40 \mathrm{mg} / \mathrm{L}$ can be explained by:

- A part of the UV radiation can be absorbed by organic molecules which reduces the quantum yield of production of radicals $\mathrm{HO}^{\bullet}$ from $\mathrm{H}_{2} \mathrm{O}_{2}$;

- Ferrous ions form stable complexes with triazine molecules;

- Auto-decomposition $\mathrm{H}_{2} \mathrm{O}_{2}$ into $\mathrm{O}_{2}$ and $\mathrm{H}_{2} \mathrm{O}$ becomes more important;

- Recombination of hydrogen peroxide and hydroxyl radicals to generate super-hydroxyl radicals.

These phenomena participate in the reduction of the efficiency of degradation of 2-chloro-4,6-diamino-1,3,5triazine by photo-Fenton process in terms of chlorine and nitrogen atoms release.

\subsubsection{Influence of the Nature of the UV Light on the Efficiency of the Photo-Fenton Process}

The source of UV irradiation has a high influence on the quantum yield of photo-decomposition of the hydrogen peroxide into hydroxyl radicals. It reported generally that the quantum yield of decomposition of $\mathrm{H}_{2} \mathrm{O}_{2}$ by UV irradiation at wavelengths between $200-300 \mathrm{~nm}$ is very close to unit. To study the influence of this parameter, we tested two types of UV light to treat aqueous solutions containing 2-chloro-4,6-diamino-1,3,5-triazine by the photo-Fenton process. The first lamp is a low pressure mercury lamp (UV-L) emitting monochromatic UV radiation of wavelength $\lambda=254 \mathrm{~nm}$. The second lamp is a medium pressure mercury lamp (UV-M) emitting polychromatic radiation between $200-600 \mathrm{~nm}$. Figure 13(a) and Figure 13(b) show the evolution of the concentrations of chlorides and nitrates during the treatment of aqueous solutions at $\mathrm{pH} 3$ containing $40 \mathrm{mg} / \mathrm{L}$ of 2-chloro4,6-diamino-1,3,5-triazine by the photo-Fenton process using $4000 \mathrm{mg} / \mathrm{L} \mathrm{H}_{2} \mathrm{O}_{2}, 5 \mathrm{mg} / \mathrm{L} \mathrm{Fe}^{2+}$, at room temperature by UV-L and UV-M irradiation. It is clear that irradiation by UV-L is more effective than the UV-M. The irradiation by UV-M resulted in the formation of $5.3 \mathrm{mg} \mathrm{Cl}^{-} / \mathrm{L}$ and $0.62 \mathrm{mg} \mathrm{NO}_{3}^{-} / \mathrm{L}$ after $480 \mathrm{~min}$ of treatment, whereas the same period of treatment $8 \mathrm{mg} \mathrm{Cl}^{-} / \mathrm{L}$ and $12.7 \mathrm{mg} \mathrm{NO}_{3}^{-} / \mathrm{L}$ were formed. This result may be related to the efficiency of the photo-decomposition of hydrogen peroxide. We followed the variation of the concentration of $\mathrm{H}_{2} \mathrm{O}_{2}$ during the irradiation of aqueous solutions containing $4000 \mathrm{mg} / \mathrm{L} \mathrm{H}_{2} \mathrm{O}_{2}$ by two types of lamp. Figure 14 shows that the photo-decomposition of $\mathrm{H}_{2} \mathrm{O}_{2}$ follows a first order kinetics for both types of UV lamp used. It is clear that the photo-decomposition of $\mathrm{H}_{2} \mathrm{O}_{2}$ by UV-L irradiation is faster than that by UV-M irradiation. The best results obtained by UV-L irradiation can be explained by more efficient production of hydroxyl radicals and direct photolysis of triazine molecules which absorb at a wavelength close to that emitted by the UV-L.

\subsection{Mechanism of Degradation of 2-Chloro-4,6-diamino-1,3,5-triazine by the Photo-Fenton Process}

The chromatographic analyses confirmed the almost total release of chlorine atoms as chloride ions and the partial release of nitrogen in the form of nitrate ions. Considering only these results, the steps involved in the degradation of 2-chloro-4,6-diamino-1,3,5-triazine by the photo-Fenton process cannot be precisely described. It is then mandatory to measure TOC and TKN during treatment of $40 \mathrm{mg} / \mathrm{L}$ triazine by the photo-Fenton process under optimal conditions. The results given in Table 2 show that TOC value remains almost constant during the treatment which indicates that there is no formation of carbon dioxide during photo-Fenton treatment of 2-chloro-4,6-diamino-1,3,5-triazine. Furthermore, Kjeldahl nitrogen decreased by an amount equivalent to the amount of nitrate formed, while total nitrogen remains invariant throughout the experiment. Analysis of TOC and TKN indicate that the degradation of 2-chloro-4,6-diamino-1,3,5-triazine by the photo-Fenton process results in the release of chlorine and amino groups substituting the triazine ring, nevertheless the triazine ring were not open because no formation of carbon dioxide was formed considering that all carbon in the molecule is assembled in the triazine ring. 


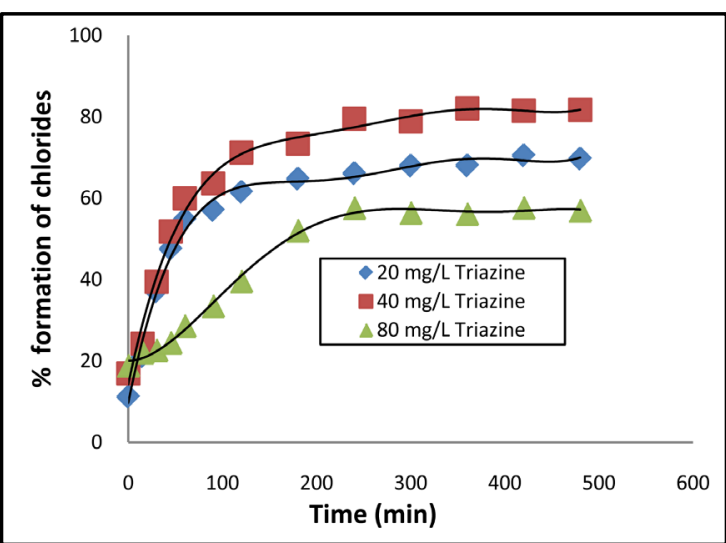

(a)

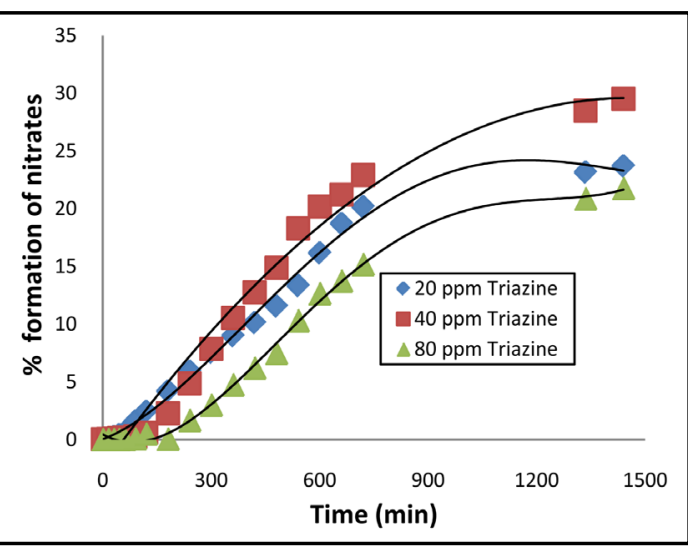

(b)

Figure 12. Influence of initial concentration of 2-chloro-4,6-diamino-1,3,5-triazine on the formation of chlorides and nitrates during the treatment of 2-chloro-4,6-diamino-1,3,5-triazine by photo-Fenton $\left(\mathrm{UV} / \mathrm{H}_{2} \mathrm{O}_{2} / \mathrm{Fe}^{2+}\right)$ process. Experimental Conditions: 20 - $80 \mathrm{mg} / \mathrm{L}$ of triazine, $4000 \mathrm{mg} / \mathrm{L} \mathrm{H}_{2} \mathrm{O}_{2}, 5 \mathrm{mg} \mathrm{Fe} \mathrm{F}^{2+} / \mathrm{L}$, UV-L (40 W) irradiation, $\mathrm{pH}$, Room temperature, $300 \mathrm{rpm}$.

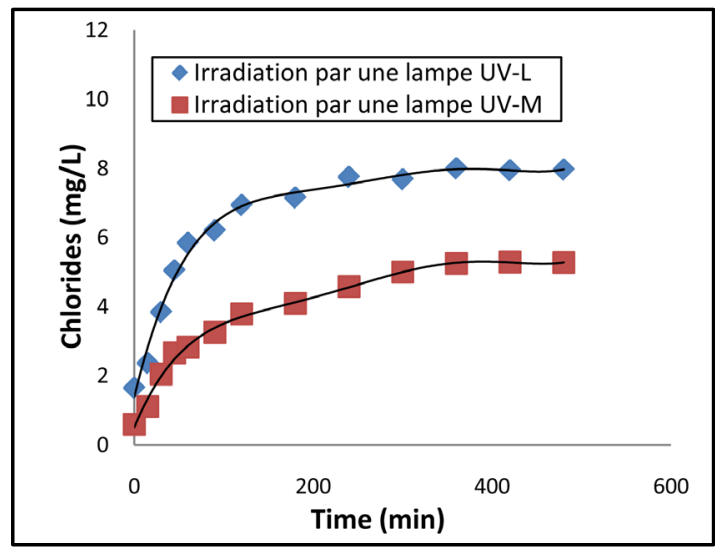

(a)

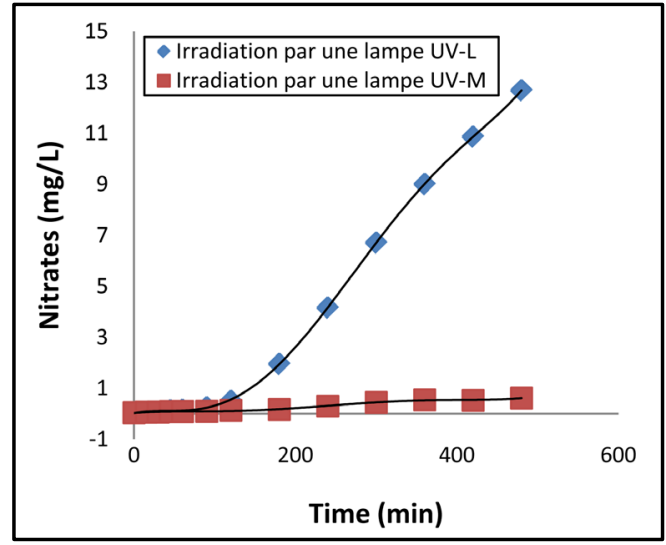

(b)

Figure 13. Influence of the nature of the UV light on the formation of ions (a) chloride; (b) nitrate during the degradation of 2-chloro-4,6-diamino-1,3,5-triazine by photo-Fenton process $\left(\mathrm{UV} / \mathrm{H}_{2} \mathrm{O}_{2} / \mathrm{Fe}^{2+}\right)$. Experimental conditions: $40 \mathrm{mg} / \mathrm{L}$ of triazine, $4000 \mathrm{mg} / \mathrm{L} \mathrm{H}_{2} \mathrm{O}_{2}, 5 \mathrm{mg} \mathrm{Fe}{ }^{2+} / \mathrm{L}, \mathrm{pH}=3$, Room temperature, $300 \mathrm{rpm}$.

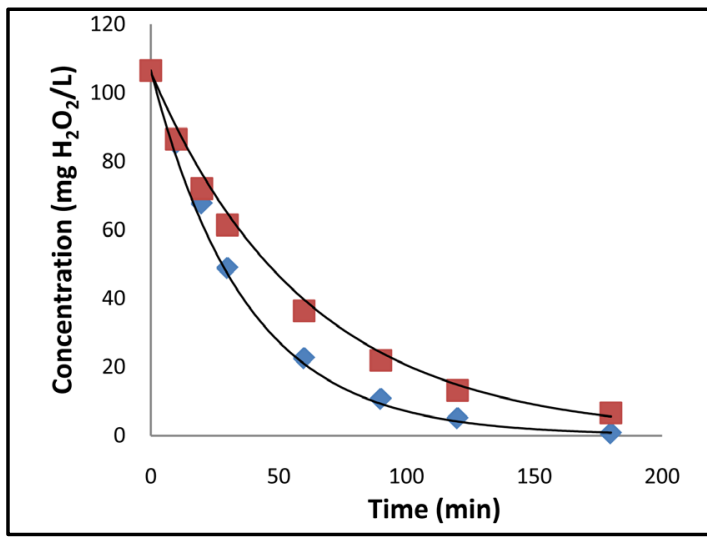

(a)

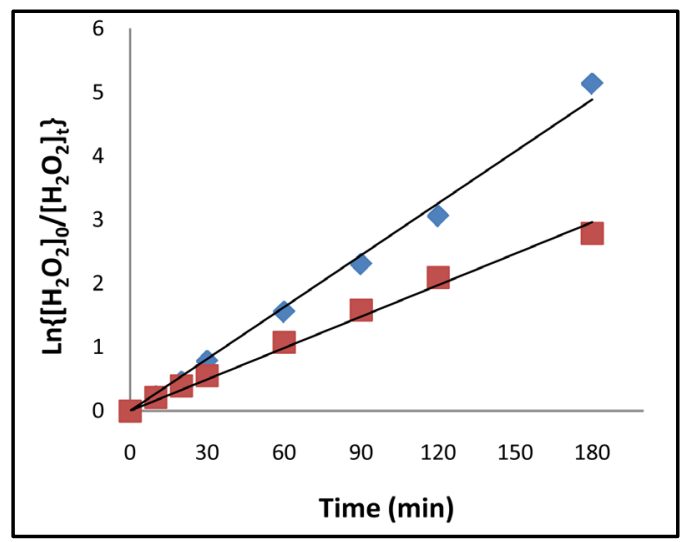

(b)

Figure 14. Kinetics of photo-decomposition of hydrogen peroxide by irradiation the light: $(\diamond)$ UV-L and ( $\square$ ) UV-M. Experimental conditions: $4000 \mathrm{mg} / \mathrm{L} \mathrm{H}_{2} \mathrm{O}_{2}$, naturel $\mathrm{pH}$, Room temperature, $300 \mathrm{rpm}$. 
Table 2. Results of TC (Total Carbon), IC (Inorganic Carbon), TOC, TN (Total Nitrogen), NN (Nitrate/Nitrite Nitrogen), and TKN analysis of 2-Chloro-4,6-diamino-1,3,5-triazine degradation using photo-Fenton process (UV-L/ $\mathrm{H}_{2} \mathrm{O}_{2} / \mathrm{Fe}^{2+}$ ). Experimental conditions: $40 \mathrm{mg} / \mathrm{L}(0.275 \mathrm{mM})$ triazine, $5 \mathrm{mg} / \mathrm{L} \mathrm{Fe}{ }^{2+}, 4000 \mathrm{mg} / \mathrm{L} \mathrm{H}_{2} \mathrm{O}_{2}$, UV-L (40 W) irradiation, $\mathrm{pH} 3.0$, room temperature $\left(23^{\circ} \mathrm{C}-25^{\circ} \mathrm{C}\right), 300 \mathrm{rpm}$.

\begin{tabular}{cccccccc}
\hline Time (min) & $\mathbf{p H}$ & $\mathbf{T C}(\mathbf{m g} \mathbf{C} / \mathbf{L})$ & $\mathbf{I C}(\mathbf{m g} \mathbf{C} / \mathbf{L})$ & $\mathbf{T O C}(\mathbf{m g} \mathbf{C} / \mathbf{L})$ & $\mathbf{T N}(\mathbf{m g} \mathbf{N} / \mathbf{L})$ & $\mathbf{N N}(\mathbf{m g} \mathbf{N} / \mathbf{L})$ & $\mathbf{T K N}(\mathbf{m g} \mathbf{N} / \mathbf{L})$ \\
\hline 0 & 3.72 & 9.87 & 0 & 9.87 & 23.32 & 0 & 23.32 \\
30 & 2.49 & 9.23 & 0 & 9.83 & 23.29 & 0 & 23.29 \\
60 & 2.59 & 7.92 & 0 & 9.62 & 23.29 & 0.23 & 23.06 \\
90 & 2.46 & 7.94 & 0 & 9.74 & 23.32 & 0.63 & 22.69 \\
120 & 2.72 & 8.58 & 0 & 9.88 & 23.33 & 0.88 & 22.45 \\
180 & 2.68 & 8.37 & 0 & 9.77 & 23.26 & 0.9 & 22.36 \\
240 & 2.77 & 9.44 & 0 & 9.84 & 23.39 & 1.29 & 22.1 \\
300 & 2.73 & 9.4 & 0 & 9.84 & 22.97 & 1.43 & 21.54 \\
360 & 2.82 & 9.3 & 0 & 9.73 & 22.93 & 1.64 & 21.29 \\
\hline
\end{tabular}

Based on chromatographic analyses and TOC and TKN results, a simple mechanistic scheme can be proposed for the degradation of 2-chloro-4,6-diamino-1,3,5-triazine by the photo-Fenton process. The main steps of this mechanism are given in Figure 15. According to the proposed mechanism, the degradation of 2-chloro-4,6-diamino-1,3,5-triazine begins by a rapid release of chlorine atoms as chloride ions and substitution of $\mathrm{Cl}$ group with hydroxyl group to form 2-hydroxy-4,6-diamino-1,3,5-triazine. This intermediate undergoes oxidation by hydroxyl radicals to convert amino groups in the nitro groups to form 2-hydroxy-4,6-dinitro-1,3,5-triazine. Nitro groups are released simultaneously or successively and are slowly substituted with hydroxyl groups. The release of the nitro groups leads to formation of nitrite which oxidizes instantly into nitrates. It appears that the final products of the degradation of 2-chloro-4,6-diamino-1,3,5-triazine by the photo-Fenton process are chloride and nitrate ions, and cyanuric acid. The formation of cyanuric as final degradation product of triazine herbicides by advanced oxidation processes has been extensively reported in the literature acid. Several researchers have demonstrated that the degradation of other triazine herbicides stops at the stage of formation of cyanuric acid due the reversibility of the exchange between hydroxyl radicals and hydroxyl groups of triazine ring. This could explain the exceptional resistance of cyanuric acid degradation by advanced oxidation processes. To confirm these hypotheses the treatment of aqueous solutions containing cyanuric acid by photo-Fenton process was undertaken.

\subsection{Degradation of Cyanuric Acid by Photo-Fenton Process}

Cyanuric acid is widely used as a stabilizer in swimming pools to prevent the destruction of chlorine by solar irradiation [39]. Although many researchers [33] [40] [41] have shown that no degradation was obtained during the treatment of this compound by hydroxyl radicals generated by various chemical and photochemical advanced oxidation processes, it is decided to study its degradation by photo-Fenton process to explain the partial mineralization of 2-chloro-4,6-diamino-1,3,5-triazine and confirm that efficiency of photo-Fenton process is mainly linked to the formation of cyanuric acid as the final product.

Degradation of cyanuric acid by photo-Fenton process was carried out under the same optimal conditions determined in the case of 2-chloro-4,6-diamino-1,3,5-triazine. In fact, aqueous solutions containing $100 \mathrm{mg} / \mathrm{L}$ cyanuric acid were treated by $4000 \mathrm{mg} / \mathrm{L} \mathrm{H}_{2} \mathrm{O}_{2}$ and $5 \mathrm{mg} / \mathrm{L} \mathrm{Fe}^{2+}$ at room temperature. Concentrations of total organic carbon (TOC) and Kjeldahl nitrogen (TKN), nitrates were measured during the treatment. Table 3 shows the TOC, TKN analysis results of cyanuric acid degradation using photo-Fenton process at different instant. These results show that the values of TOC are invariant during the treatment, while the TKN has been a slight decrease to the end of treatment. Very low amount of nitrates not exceeding $0.5 \mathrm{mg} \mathrm{N} / \mathrm{L}$ were measured after ten hours of treatment. The amount of nitrate measured at the end of treatment has certainly resulted from irradiation by UV light because after 10 hours of treatment the hydrogen peroxide was completely decomposed. We also 


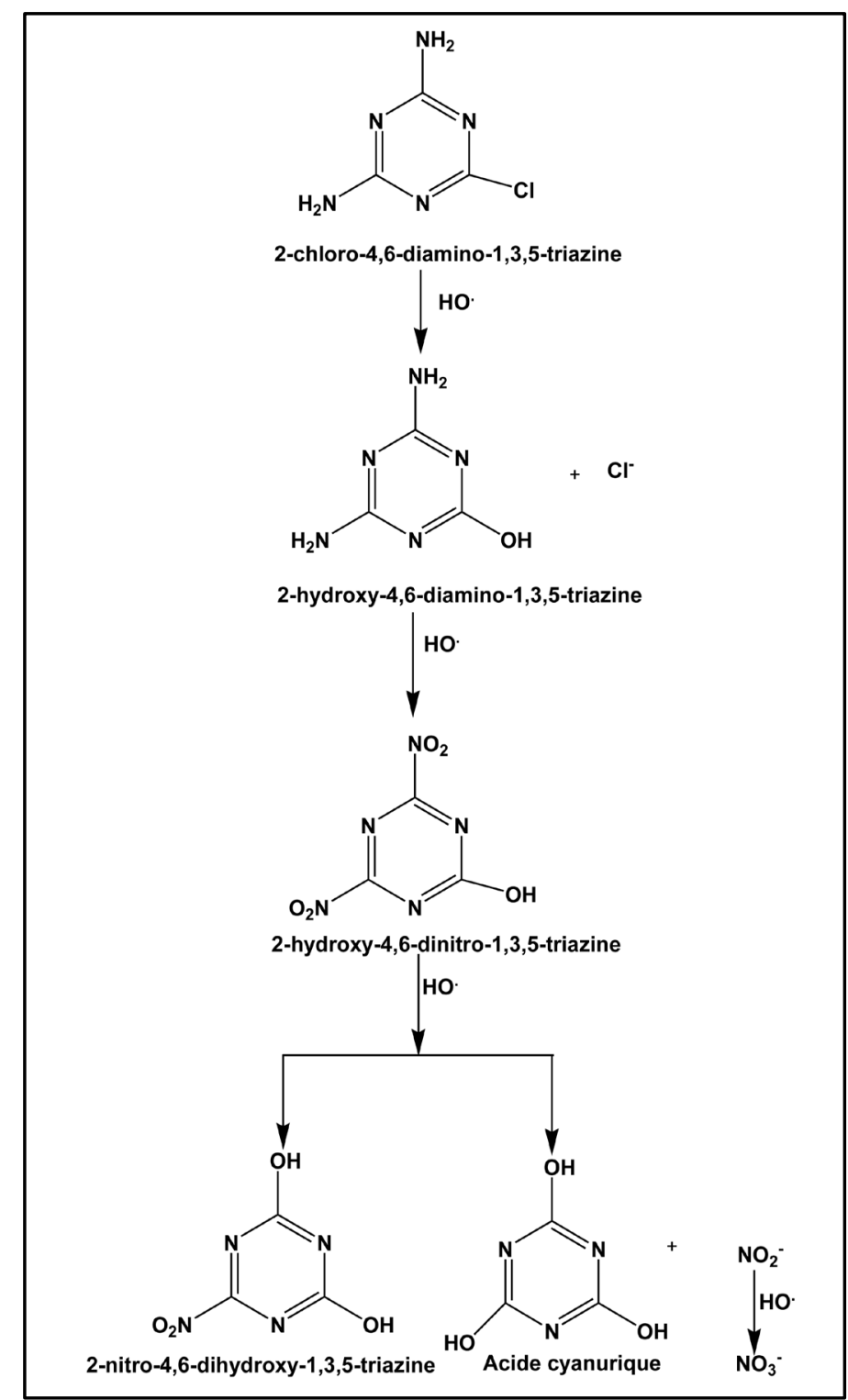

Figure 15. Simple mechanism proposed for the degradation of 2chloro-4,6-diamino-1,3,5-triazine by photo-Fenton process.

studied the influence of initial $\mathrm{pH}$ on the degradation of cyanuric acid. The results obtained at pH 3, 5.4, 7 and 9 coincide with those presented in Table 2. The overall results obtained have shown that no formation of carbon dioxide and nitrate were formed during photo-Fenton treatment of aqueous solutions containing $100 \mathrm{mg} / \mathrm{L}$ cyanuric acid. They are in good agreement with the results reported by Tetzlaff and Jenks, [41]. These researchers showed resistance of cyanuric acid by photocatalytic processes. The resistance of the cyanuric acid degradation by photo-Fenton process can be explained by: 1) No possibilityto oxidize the organic carbon of cyanuric acid because all carbon atoms are in the highest oxidation state (+IV); 2) the reversibility of exchange between hydroxyl radicals and $\mathrm{OH}$ groups of thetriazinic ring; 3 ) the formation of very stable complexes between ferrous or ferric iron and cyanuric acid molecules.

\section{Conclusion}

The results obtained have shown that the degradation of 2-chloro-4,6-diamino-1,3,5-triazine by photo-Fenton process is more rapid and effective than Fenton and $\mathrm{UV} / \mathrm{H}_{2} \mathrm{O}_{2}$ processes. This can be explained by the additional 
Table 3. Results of TC, IC,TOC, TN, NN, TKN, and nitrate analysis of cyanuric acid degradation using photo-Fenton process (UV/ $\mathrm{H}_{2} \mathrm{O}_{2} / \mathrm{Fe}^{2+}$ ). Experimental conditions: $100 \mathrm{mg} / \mathrm{L}$ cyanuric acid, $4000 \mathrm{mg} / \mathrm{L} \mathrm{H}_{2} \mathrm{O}_{2}, 5 \mathrm{mg} \mathrm{Fe}{ }^{2+} / \mathrm{L}$, natural $\mathrm{pH}$, room temperature, $300 \mathrm{rpm}$.

\begin{tabular}{cccccccc}
\hline Time (min) & TC (mgC/L) & IC (mgC/L) & TOC $(\mathbf{m g C} / \mathbf{L})$ & TN $(\mathbf{m g N} / \mathbf{L})$ & $\mathbf{N N}(\mathbf{m g N} / \mathbf{L})$ & TKN (mgN/L) & Nitrate (mg/L) \\
\hline 0 & 32.08 & 0 & 32.08 & 38.32 & 0 & 38.32 & 0.052 \\
15 & 31.6 & 0 & 31.6 & 38.36 & 0 & 38.36 & 0.056 \\
30 & 30.09 & 0 & 30.09 & 37.54 & 0 & 37.54 & 0.058 \\
45 & 31.82 & 0 & 31.82 & 37.6 & 0 & 37.6 & 0.044 \\
60 & 31.32 & 0 & 31.32 & 36.9 & 0 & 36.9 & 0.062 \\
90 & 32 & 0 & 32 & 37.1 & 0 & 37.1 & 0.071 \\
120 & 31.73 & 0 & 31.73 & 37.34 & 0 & 37.34 & 0.091 \\
180 & 31.95 & 0 & 31.95 & 37.38 & 0 & 37.38 & 0.175 \\
240 & 32.02 & 0 & 32.02 & 36.92 & 0 & 36.92 & 0.326 \\
300 & 30.84 & 0 & 30.84 & 37.68 & 0 & 37.68 & 0.474 \\
360 & 30.49 & 0 & 30.49 & 36.96 & 0 & 36.96 & 0.741 \\
420 & 30.63 & 0 & 30.63 & 36.50 & 0 & 36.50 & 0.905 \\
480 & 30.63 & 0 & 30.63 & 36.08 & 0 & 38.08 & 1.133 \\
540 & 30.88 & 0 & 30.88 & 35.36 & 0 & 35.36 & 1.514 \\
600 & 30.73 & 0 & 30.73 & 35.12 & 0 & 35.12 & 2.01 \\
\hline
\end{tabular}

hydroxyls radicals produced by catalytic and photo-decomposition of $\mathrm{H}_{2} \mathrm{O}_{2}$. The study of the influence of certain experimental parameters on the efficiency of the photo-Fenton process was used to determine the optimal conditions for degradation $40 \mathrm{mg} / \mathrm{L}$ of 2-chloro-4,6-diamino-1,3,5-triazine at room temperature: an initial pH about 3, an initial concentration of hydrogen peroxide of the order of $4000 \mathrm{mg} / \mathrm{L}$, a ferric iron dose not exceeding $5 \mathrm{mg} / \mathrm{L}$ and $300 \mathrm{rpm}$. In optimized operating conditions, photo-Fenton process achieved more than $90 \%$ of chloride release and about $28 \%$ of nitrate formation. By cons TOC and TKN analysis has shown that no carbon dioxide and ammonia were formed during photo-Fenton treatment of aqueous solutions. These results indicated that only the substituent groups (chloro and amino groups) are released; however, nitrogen atoms of triazine ring are stable. Also, the experiences of cyanuric acid degradation by photo-Fenton process indicated that no formation of carbon dioxide and nitrate was obtained. These results confirmed those reported in the literature [40] [41] that indicated that cyanuric acid is resistant to oxidation by hydroxyl radical which explains why no further nitrate ions and no carbon dioxide are formed for long period irradiation experiments.

\section{References}

[1] Duguet, J.P. (1994) Occurrence of Pesticides in Natural Waters and Removal Duringdrinking Water Treatment Processes. Water Supply, 12, 111-115.

[2] Konstantinou, I.K., Hela, D.G. and Albanis, T.A. (2006) The Status of Pesticide Pollution Insurface Waters (Rivers and Lakes) of Greece. Part I: Review on Occurrence and Levels. Environmental Pollution, 141, 555-570. http://dx.doi.org/10.1016/j.envpol.2005.07.024

[3] Stamatis, N., Konstantinou, I. and Hela, D. (2010) Pesticide Inputs from the Sewage Treatment Plant of Agrinio to River Acheloos, Western Greece: Occurrence and Removal. Water Science and Technology, 62, 1098-1105. http://dx.doi.org/10.2166/wst.2010.932

[4] Sinha, S., Rao, M., Vasudev, K. and Odetokun, M. (2012) A Liquid Chromatography Mass Spectrometry-Based Method to Measure Organophosphorous Insecticide, Herbicide and Non-Organophosphorous Pesticide in Grape and Apple Samples. Food Control, 25, 636-646. http://dx.doi.org/10.1016/j.foodcont.2011.11.031

[5] Griffini, O., Bao, M.L., Barbieri, C., Burrini, D. and Pantani, F. (1997) Occurrence of Pesticides in the Arno River and 
in Potable Water-A Survey of the Period 1992-1995. Bulletin of Environmental Contamination and Toxicology, 59, 202-209. http://dx.doi.org/10.1016/j.foodcont.2011.11.031

[6] Giudice, B.D., Massoudieh, A., Huang, X. and Young, T.M. (2008) A Stochastic Simulation Procedure for Selecting Herbicides with Minimum Environmental Impact. Environmental Science Technology, 42, 354-360. http://dx.doi.org/10.1021/es070959n

[7] Glæsner, N., Bælum, J., Strobel, B.W. and Jacobsen, C.S. (2010) Atrazine Is Not Readily Mineralized in 24 Temperate Soils Regardless of Pre-Exposure to Triazine Herbicides. Environmental Pollution, 158, 3670-3674. http://dx.doi.org/10.1016/j.envpol.2010.07.039

[8] Dombek, T., Davis, D., Stine, J. and Klarup, D. (2004) Degradation of Terbutylazine (2-Chloro-4-ethylamino-6-terbutylamino-1,3,5-Triazine), Deisopropyl Atrazine (2-Amino-4-chloro-6-ethylamino-1,3,5-triazine), and Chlorinated Dimethoxy Triazine (2-Chloro-4,6-dimethoxy-1,3,5-triazine) by Zero Valent Iron and Electrochemical Reduction. Environmental Pollution, 129, 267-275. http://dx.doi.org/10.1016/j.envpol.2003.10.008

[9] Kim, S.Y., Jo, Y.A., Choi, J. and Choi, M.J. (2001) Characterization of s-Triazine Antibodies and Comparison of Enzyme Immunoassay for the Determination of s-Triazine. Microchemical Journal, 68, 163-172. http://dx.doi.org/10.1016/S0026-265X(00)00143-0

[10] Singh, P., Suri, C.R. and Cameotra, S.S. (2004) Isolation of a Member of Acinetobacter Species Involved in Atrazine Degradation. Biochemical and Biophysical Research Communications, 317, 697-702. http://dx.doi.org/10.1016/j.bbrc.2004.03.112

[11] Bensalah, N., Khodary, A. and Abdel-Wahab, A. (2011) Kinetic and Mechanistic Investigations of Mesotrione Degradation in Aqueous Medium by Fenton Process. Journal of Hazardous Materials, 189, 479-485. http://dx.doi.org/10.1016/j.jhazmat.2011.02.060

[12] De Laat, J., Le, G.T. and Legube, B. (2004) A Comparative Study of the Effects of Chloride, Sulfate and Nitrate Ions on the Rates of Decomposition of $\mathrm{H}_{2} \mathrm{O}_{2}$ and Organic Compounds by $\mathrm{Fe}(\mathrm{II}) / \mathrm{H}_{2} \mathrm{O}_{2}$ and $\mathrm{Fe}(\mathrm{III}) / \mathrm{H}_{2} \mathrm{O}_{2}$. Chemosphere, 55, 715-723. http://dx.doi.org/10.1016/j.chemosphere.2003.11.021

[13] Virender, K., Theodoros, M., Maria, G., X.X., He, Miguel, P., Changseok, H., Weihua, S., Kevin, E., Armah, A., Triantafyllos, K., Anastasia, H. and Dionysios, D. (2012) Destruction of Microcystins by Conventional and Advanced Oxidation Processes: A Review. Separation and Purification Technology, 91, 3-17. http://dx.doi.org/10.1016/j.seppur.2012.02.018

[14] Neamtu, M., Yediler, A., Siminiceanu, I., Macoveanu, M. and Kettrup, A. (2004) Decolourization of Disperse Red 354 Azo Dye in Water by Several Oxidation Processes-A Comparative Study. Dyes and Pigments, 60, 61-68. http://dx.doi.org/10.1016/S0143-7208(03)00129-3

[15] Chan, C.Y., Tao, S., Dawson, R. and Wong, P.K. (2004) Treatment of Atrazine by Integrating Photocatalytic and Biological Processes. Environmental Pollution, 131, 45-54. http://dx.doi.org/10.1016/j.envpol.2004.02.022

[16] Hua, W., Bennett, E.R. and Letcher, R.J. (2006) Ozone Treatment and the Depletion of Detectable Pharmaceuticals and Atrazine Herbicide in Drinking Water Sourced from the Upper Detroit River, Ontario, Canada. Water Research, 40, 2259-2266. http://dx.doi.org/10.1016/j.watres.2006.04.033

[17] Muñoz, I., Peral, J., Ayllon, L.J., Malato, S., Passarinho, P. and Domenech, X. (2006) Life Cycle Assessment of a Coupled Solar Photocatalytic-Biological Process for Waste Water Treatment. Water Research, 40, 3533-3540. http://dx.doi.org/10.1016/j.watres.2006.08.001

[18] Bedoui, A., Elsaid, K., Bensalah, N. and Abdel-Wahab, A. (2011) Treatment of Pharmaceutical-Manufacturing Wastewaters by UV Irradiation/Hydrogen Peroxide Process. Journal of Advanced Oxidation Technologies, 14, $226-234$.

[19] Ahmed, B., Mohamed, H., Limem, E. and Nasr, B. (2009) Degradation and Mineralization of Organic Pollutants Contained in Actual Pulp and Paper Mills Wastewaters by a UV/ $\mathrm{H}_{2} \mathrm{O}_{2}$ Process. Industrial and Engineering Chemistry Research, 48, 3370-3379. http://dx.doi.org/10.1021/ie801755u

[20] Konstantinou, K.I. and Albanis, A.T. (2003) Photocatalytic Transformation of Pesticides in Aqueous Titanium Dioxide Suspensions Using Artificial and Solar Light: Intermediates and Degradation Pathways. Applied Catalysis B: Environmental, 42, 319-335. http://dx.doi.org/10.1016/S0926-3373(02)00266-7

[21] Ahmed, B., Limem, E., Abdel-Wahab, A. and Nasr, B. (2011) Photo-Fenton Treatment of Actual Agro-Industrial Wastewaters. Industrial and Engineering Chemistry Research, 50, 6673-6680. http://dx.doi.org/10.1021/ie200266d

[22] Martín, B.M.M., Pérez, S.J.A., Fernández, A.F.G., López, J.L., Garcia-Ripoll, A.M., Arques, I.O. and Rodrıguez, S.M. (2008) Combined Photo-Fenton and Biological Oxidation for Pesticide Degradation: Effect of Photo-Treated Intermediates on Biodegradation Kinetics. Chemosphere, 70, 1476-1483. http://dx.doi.org/10.1016/j.chemosphere.2007.08.027

[23] Elahmadi, M.F., Bensalah, N. and Gadri, A. (2009) Treatment of Aqueous Wastes Contaminated with Congo Red Dye by Electrochemical Oxidation and Ozonation Processes. Journal of Hazardous Materials, 168, 1163-1169. http://dx.doi.org/10.1016/j.jhazmat.2009.02.139 
[24] Oturan, N., Hamza, M., Ammar, S., Abdelhédi, R. and Oturan, M.A. (2011) Oxidation/Mineralization of 2-Nitrophenol in Aqueous Medium by Electrochemical Advanced Oxidation Processes Using Pt/Carbon-Felt and BDD/Carbon-Felt Cells. Journal of Electroanalytical Chemistry, 661, 66-71. http://dx.doi.org/10.1016/j.jelechem.2011.07.017

[25] Comninellis, C., Kapalka, A., Malato, S., Parsons, S.A., Poulios, I. and Mantzavinos, D. (2008) Advanced Oxidation Processes for Water Treatment: Advances and Trends for R\&D. Journal of Chemical Technology and Biotechnology, 83, 769-776. http://dx.doi.org/10.1002/jctb.1873

[26] Andreozzi, R., Caprio, V., Insola, A. and Marotta, R. (1999) Advanced Oxidation Processes (AOP) for Water Purification and Recovery. Catalysis Today, 53, 51-59. http://dx.doi.org/10.1016/S0920-5861(99)00102-9

[27] Pignatello, J.J., Oliveros, E. and Mackay, A. (2006) Advanced Oxidation Processes for Organic Contaminant Destruction Based on the Fenton Reaction and Related Chemistry. Critical Reviews in Environmental Science and Technology, 36, 1-84. http://dx.doi.org/10.1080/10643380500326564

[28] Kaichouh, G., Oturan, N., Oturan, M.A., ElHourch, A. and Elkacemi, K. (2008) Mineralization of Herbicides Imazapyr and Imazaquin in Aqueous Medium by Fenton, Photo-Fenton and Electro-Fenton Processes. Environmental Technology, 29, 489-496. http://dx.doi.org/10.1080/09593330801983516

[29] Hladik, M.L., Bouwer, E.J. and Roberts, A.L. (2008) Neutral Degradates of Chloroacetami Deherbicides: Occurrence in Drinking Water and Removal during Conventional Water Treatment. Water Research, 42, 4905-4914. http://dx.doi.org/10.1016/j.watres.2008.09.008

[30] Borras, N., Oliver, R., Arias, C. and Brillas, E. (2010) Degradation of Atrazine by Electrochemical Advanced Oxidation Processes Using a Boron-Doped Diamond Anode. Journal of Physical Chemistry A, 114, 6613-6621. http://dx.doi.org/10.1021/jp1035647

[31] Oturan, N., Brillas, E. and Oturan, M.A. (2012) Unprecedented Total Mineralization of Atrazine and Cyanuric Acid by Anodic and Electro-Fenton with a Boron-Doped Diamond Anode. Environmental Chemistry Letters, 10, 165-170. http://dx.doi.org/10.1007/s10311-011-0337-z

[32] Bandala, E.R., Dominguez, Z., Rivas, F. and Gelover, S. (2007) Degradation of Atrazine Using Solar Driven FentonLike Advanced Oxidation Processes. Journal of Environmental Science and Health, Part B: Pesticides, Food Contaminants, and Agricultural Wastes, 42, 21-26. http://dx.doi.org/10.1080/03601230601017965

[33] Watanabe, N., Horikoshi, S., Hidaka, H. and Serpone, N. (2005) On the Recalcitrant Nature of the Triazinic Ring Species, Cyanuric Acid, to Degradation in Fenton Solutions and in UV-Illuminated $\mathrm{TiO}_{2}$ (Naked) and Fluorinated $\mathrm{TiO}_{2}$ Aqueous Dispersions. Journal of Photochemistry and Photobiology A: Chemistry, 174, 229-238. http://dx.doi.org/10.1016/j.jphotochem.2005.03.013

[34] Ravichandran, L., Selvam, K. and Swaminathan, M. (2007) Photo-Fenton Defluoridation of Pentafluorobenzoic Acid with UV-C Light. Journal of Photochemistry and Photobiology A: Chemistry, 188, 392-398. http://dx.doi.org/10.1016/j.jphotochem.2006.12.041

[35] Cesaro, A., Naddeo, V. and Belgiorno, V. (2013) Wastewater Treatment by Combination of Advanced Oxidation Processes and Conventional Biological Systems. Journal of Bioremediation Biodegradation, 4, 208. http://dx.doi.org/10.4172/2155-6199.1000208

[36] Rathi, A., Rajor, H.K. and Sharma, R.K. (2003) Photodegradation of Direct Yellow-12 Using UV/ $\mathrm{H}_{2} \mathrm{O}_{2} / \mathrm{Fe}^{2+}$. Journal of Hazardous Materials, 102, 231-241. http://dx.doi.org/10.1016/S0304-3894(03)00213-9

[37] Szumera, J., Wetniak, M., Olejniczak, A. and Lukaszewicz, J.P. (2010) Transfer of Triazine-Iron(II) Chromic Complexes Left by Iron Items on Textile Background and Human Skin. Journal of Forensic Sciences, 55, 944-952. http://dx.doi.org/10.1111/j.1556-4029.2010.01333.x

[38] Gun, J., Ekeltchik, I., Lev, O., Shelkov, R. and Melman, A. (2005) Bis-(Hydroxyamino) Triazines: Highly Stable Hydroxylamine-Based Ligands for Iron(III) Cations. Chemical Communications, 42, 5319-5321. http://dx.doi.org/10.1039/b508138f

[39] Yu, C., Zhu, L., Xiao, J., Tang, H., Guo, G., Zeng, Q. and Wang, X. (2009) Ultrasonic Extraction and Determination of Cyanuric Acid in Pet Food. Food Control, 20, 205-208. http://dx.doi.org/10.1016/j.foodcont.2008.04.004

[40] Oh, Y.C. and Jenks, W.S. (2004) Photocatalytic Degradation of a Cyanuric Acid, a Recalcitrant Species. Journal of Photochemistry and Photobiology A: Chemistry, 162, 323-328. http://dx.doi.org/10.1016/S1010-6030(03)00372-1

[41] Tetzlaff, T.A. and Jenks, W.S. (1999) Stability of Cyanuric Acid to Photocatalytic Degradation. Organic Letters, 1, 463-465. http://dx.doi.org/10.1021/ol9906662 